\title{
GLOBALIZAÇÃO E INDIVIDUALIZAÇÃO NA MODERNIDADE TARDIA. UMA INTRODUÇÃO TEÓRICA À SOCIOLOGIA DA JUVENTUDE ${ }^{12}$
}

\author{
Frédéric Vandenberghe $e^{3}$
}

\begin{abstract}
RESUMO
0 artigo oferece uma análise programática de algumas das principais teorias da modernização, da globalização e da individualização na modernidade tardia, conectando essa análise à sociologia da juventude. 0 texto se divide em quatro partes: a primeira provê um panorama dos debates sobre a modernidade e distingue várias posições no seio destes (clássica, anti, pós e neo); a segunda parte propõe um quadro
\end{abstract}

1 Nota do Editor: Manuscrito publicado em italiano sob o título Globalizzazione $e$ individualizzazione nella tarda modernità. In: Bettin, G. (a cura di): Giovani e democrazia in Europa, Tomo 1, Cedam, Padova, 1999, pp. 3-68. A Comissão Editorial agradece ao autor por autorizar esta publicação. Traduzido do original em inglês por Carusa Gabriela Biliatto. Revisão técnica de Frédéric Vandenberghe. Edição e revisão de Martha Ramírez-Gálvez.

${ }^{2} 0$ texto foi escrito originalmente em 1998, em língua inglesa, para publicação em língua italiana. Contudo, o manuscrito em língua inglesa permaneceu em meu arquivo pessoal até Danilo Arnaut convidar-me para publicá-lo na revista Ideias. Por inteira coincidência, independente da iniciativa de Danilo, Carusa Gabriela propôs traduzir o texto para língua portuguesa. Dessa coincidência resulta que o texto será publicado, simultaneamente, em Ideias e em Mediações, na versão em inglês e em português, respectivamente. Agradeço a ambos, Danilo e Carusa, pela solicitude e à Carusa pelo esforço da tradução. Thanks! Foi um prazer trabalhar com ela na revisão da tradução. Inseri ligeira atualização, todavia, não o suficiente para realocar e responder ao contexto brasileiro. Se o texto ainda possui algum valor após todos esses anos, suponho que isto se vincula ao texto de Anthony McGrew (1992) e de Ulrich Beck (1997), que me inspiraram, e ao propositivo esquema analítico para o entendimento da globalização e da individualização na modernidade tardia.

${ }^{3}$ Professor e pesquisador no Instituto de Estudos Sociais e Políticos da Universidade do Estado do Rio de Janeiro (IESP-UERJ), Brasil. frederic@iesp.uerj.br 
de referência multidimensional para a análise da globalização, o qual integra seus aspectos econômicos, políticos e culturais em uma narrativa coerente; a terceira parte apresenta as teorias da sociedade de risco, da modernização reflexiva e da individualização reflexiva de Ulrich Beck e Anthony Giddens; finalmente, a última parte costura todos os fios da análise em uma teoria sociológica da juventude, do pósmaterialismo e dos novos movimentos sociais.

Palavras-chave: Globalização. Modernização e individualização. Novos movimentos Sociais. Juventude.

\section{GLOBALIZATION AND INDIVIDUALIZATION IN LATE MODERNITY: A THEORETICAL INTRODUCTION TO THE SOCIOLOGY OF YOUTH}

\section{ABSTRACT}

The article provides a programmatic analysis of some of the main theories of modernization, globalization and individualization in late modernity, connecting this analysis to the sociology of youth. The text is divided into four sections: the first provides an overview of debates about modernity and distinguishes various positions within them (classical, anti, post and neo); the second section proposes a multidimensional framework of reference for the analysis of globalization, integrating its economic, political and cultural aspects in a coherent narrative; the third section presents the theories of risk society, reflexive modernization and the reflexive individualization of Ulrich Beck and Anthony Giddens; the last section intertwines all of the threads of the analysis into a sociological theory of youth, post-materialism and new social movements.

Keywords: Globalization. Modernization and individualization. New social movements. Youth.

$\mathrm{N}$ ão há sociologia da juventude sem "imaginação sociológica". Com ligeiro exagero, podemos dizer que a Imaginação Sociológica, de Mills (1957), representa a contrapartida sociológica de A crítica da razão pura de Kant. Da mesma forma que a realidade empírica somente pode ser entendida a partir da mediação por categorias do entendimento, as tribulações das juventudes contemporâneas apenas podem ser entendidas se sua vida cotidiana for interpretada em relação de contrapartida ao longo contexto histórico da modernidade tardia. Desacoplada desse contexto, a análise sociológica da 
juventude arrisca permanecer presa à coleção etnográfica meramente descritiva de histórias e estilos de vida ou, por outro lado, ainda pior, à contraproducente manipulação de correlações e regressões estatísticas. Em franca oposição à tendência empirista à acumulação fetichista de dados brutos, que apenas faz sentido - como os filósofos pós-positivistas bem sabem - porque eles estão sobredeterminados pela teoria, ocupar-me-ei neste artigo com o esboço de um esquema teórico para a análise das juventudes.

Eventualmente, este esquema teórico - que está inspirado, entre outros, pelas teorias sobrepostas de Ulrich Beck e Anthony Giddens sobre a modernidade tardia - nos permitirá visualizar como as categorias do existencial e do socialhistórico de Mills; ou as de local e global, para usar uma linguagem em voga, podem ser categorias significativamente interconectadas de tal maneira que 0 termo "juventude" não possa mais ser visto como marginal, no duplo sentido do termo - de ser um ator histórico supostamente sem poder e de ser uma área específica de pesquisa que está fora da teoria sociológica de vanguarda.

Para levar o "tema marginal" ao centro da vida social e da teoria sociológica, proponho reconectar à sociologia da juventude a sociologia da mudança social, em geral, e à sociologia da modernidade tardia, em particular. 0 artigo está organizado em quatro partes. Na primeira, apresento uma rápida visão panorâmica das teorias da modernidade que se sucederam desde 0 nascimento da sociologia no século XIX. A sucessão de teorias da modernidade - que são mnemonicamente indicadas pelos prefixos clássico, anti, pós, neo e tardia oferece uma chave para um conhecimento preambular para uma sintética teoria da modernidade tardia. Por sua vez, a teoria da modernidade tardia forma 0 contexto para a análise do processo dual de globalização e de individualização que, respectivamente, são analisados na parte dois e três do presente texto.

A ideia principal que subjaz e conecta a análise da globalização e da individualização acompanha, em simultâneo, aquela de uma sociologia crítica da modernidade tardia localizada conceitualmente como multidimensional (VANDENBERGHE, 1997-1998). Não se pode contentar com uma análise estrutural da dominação, mas se deve também indicar forças possíveis de emancipação individual e de transformação social. Da mesma forma como a macrossociologia do sistema necessita ser complementada pela micro-análise do mundo da vida, por consequência, a análise economicamente dirigida do processo da globalização deve, por sua vez, ser acrescentada a uma análise de processos emancipatórios de individualização que estão, ao mesmo tempo, acontecendo no mundo da vida e que poderiam, potencialmente, inflexionar o processo de 
globalização na direção de uma ordem pós-materialista de desenvolvimento sustentável, que não é apenas socialmente sensível como também responsável ecologicamente. ${ }^{4}$ No seio desta problemática, será inserida a questão das juventudes. Já na parte quatro, analisarei a situação das juventudes na modernidade tardia e mostrarei como o duplo processo de globalização e de individualização afeta as transições para a idade adulta e a vida política. Por este caminho, a juventude não será considerada como categoria biológica, mas, primeiro, como categoria sociológica, definida em termos de transição de status próprios a uma geração e interpretada culturalmente; segundo, politicamente como uma instância dos novos movimentos sociais e culturais que se esforçam e lutam por orientações normativas capazes de determinar a direção do desenvolvimento social.

\section{MODERNIDADE: CLÁSSICA, MODERNA, ANTI, PÓS, NEO E TARDIA}

A sociologia emergiu ao longo do século XIX (1789-1914) junto ao advento da modernidade e não pode ser desvinculada disso. Uma vez que a sociologia é reflexivamente amarrada à modernidade e que a modernidade é intrinsecamente associada ao dinamismo sociocultural e à "destruição criativa" dos retalhos do passado (BERMAN, 1982), então, não é surpresa alguma o fato de que a análise da mudança social tenha sido um, se não o tópico central da sociologia. A distinção disciplinar oitocentista entre antropologia, entendida inicial e estreitamente como o estudo das sociedades "sem história", por um lado, e, por outro lado, sociologia, entendida como o estudo da modernidade, pode (e deve) ser revisto completamente. No entanto, ela tem a vantagem de explicitar a conexão entre historicidade, mudança social e modernidade. Olhando para a história da sociologia, que pode também ser lida como uma transcrição teórica da mudança social dos últimos séculos, nós podemos distinguir, no mínimo, cinco diferentes períodos teórico-ideológicos da teorização sobre a mudança social ${ }^{5}$ : (I) a teoria

\footnotetext{
${ }^{4}$ Para usar o subjuntivo, quero indicar e explorar o potencial de desenvolvimentos contrafactuais no seio do mundo da vida. Desnecessário dizer, o modo contrafactual de pensar serve principalmente como uma função heurística e deontológica: a extrapolação do presente para 0 futuro indica para 0 que pode e deve ocorrer se determinadas circunstâncias que, todavia, não estão realizadas no presente fossem, contudo, realizadas.

${ }^{5}$ Esses períodos sucessivos de teorização sobre a modernidade podem ser indicados pelo mnemônico estratagema: clássico, anti, pós, neo, e tardio (ALEXANDER, 1994). Além de uma sucessão de teorias também reflete mudanças socio-históricas. A maneira de considerar os mencionados prefixos não é somente destinada a referir modos historicamente variáveis de leitura, mas também para referir as mudanças socio-históricas da realidade social. 0 principal benefício
} 
clássica da modernidade como formulada pelos "pais fundadores" da sociologia; (II) a teoria do pós-guerra e sua inversão ideológica na teoria da modernização dos anos de 1960 e 1970; (III) a teoria pós-moderna dos anos de 1980; (IV) a teoria neomoderna da democratização e, por último, porém não menos importante, (V) a teoria sociológica da modernidade tardia, considerada uma síntese crítica dos anteriores estratos teóricos mencionados.

Desde a virada do milênio, o mundo encontra-se em viração tumultuosa. A conjunção das revoluções geopolítica, econômica e tecnológica está mudando os contornos do mundo, como nós sabemos. Embora eu considere que as mais recentes mudanças sociais sejam tão radicais, que permitem a afirmação um tanto peremptória de que a modernidade tardia tem atingido seu fim e que estamos face à emergência de uma nova civilização (VANDENBERGHE, 2014, p. 265-329), não pretendo apresentar argumentos aptos a decifrar a conjuntura corrente. Até mesmo duvido se a sociologia, disciplina dos séculos XIX e XX, está particularmente bem alocada para propor uma ontologia do presente. Estes, sobre nós, são tempos transicionais. Semelhante à maioria, estou tomado pela neblina. Por conseguinte, para manter a cautela, convido o leitor a considerar minha análise como uma análise do passado recente - válida até 2007, talvez, mas não além.

\section{0-1933: Teoria Clássica da Modernidade}

No período clássico (1840-1933), cada um dos "pais fundadores" da sociologia - Emile Durkheim, Karl Marx e Max Weber - apresentaram uma "interpretação descontinuista da história moderna", segundo a qual o advento da modernidade representa uma quebra tão profunda com as sociedades tradicionais que as sociedades que emergiram no Ocidente nos séculos XVIII e XIX se distinguem radicalmente de todas as prévias formas de ordem social e precisam, portanto, de uma nova disciplina para entender e acompanhar a ruptura (GIDDENS, 1985, p.31-34; 1990, p.1-6). Embora os "pais fundadores" não concordem sobre as especificidades e indiquem diferentes processos de modernização, respectivamente, diferenciação funcional, comodificação e racionalização (CROOK, PAKULSKI; WATERS, 1992, p. 2-9), nós podemos, no

de semelhante dupla conceitualização da modernidade ao longo de dois eixos, quais seja, interpretativo e sócio-histórico desde as propriedades especificadoras dos dois modos, é o fato de que leva em conta a justaposição dos modos de leitura e dos modos de ser. Adotando esta perspectiva, podemos, portanto, não somente oferecer uma pós (ou anti) moderna leitura da modernidade, não obstante, porquanto, uma clássica (ou tardia) leitura das pós-modernidades. 
entanto, estar seguros de que os mencionados processos de mudança social por eles descritos são amplamente complementares e que suas análises da modernidade convergem em uma grande narrativa empírica da mudança social. Nessa grande narrativa, a relativa autonomização das estruturas sociais funcionalmente diferenciadas - por exemplo, o mercado da economia ou a administração burocrática do Estado e a progressiva erosão da tradição e dos laços de solidariedade considerados, então, laços naturais - aparecem como características distintas da "grande transição" para a modernidade.

Combinando uma teoria geral da modernização a um diagnóstico crítico da ambivalência da modernidade, os fundadores da sociologia consideraram como a principal causa das patologias da modernidade a difusão geral e a generalização da "ação racional em relação a um fim" (Weber) ou do "modo estratégico da ação" (Habermas) oriundo do domínio da esfera econômica penetrando, então, em todos os demais domínios da vida. De fato, sem muita hesitação, nós podemos inclusive dizer que a sociologia foi desde o seu mais tenro início engajada em um combate contra a hegemonia teórica e prática do utilitarismo (CAILLÉ, 1988, p. 24-32). Contestando as opções do individualismo utilitarista, a tradição clássica da sociologia era envolvida por uma tentativa política para revigorar e defender um "individualismo institucional" (Durkheim) eticamente inspirado, o qual se prontifica a interrelacionar as leituras de liberdade da modernidade e de solidariedade do passado.

Apesar das indicadas convergências, deve ser notado que o diagnóstico de Durkheim e Mauss sobre as patologias da modernidade diferiam significativamente, em um sentido, de seus oponentes germânicos. Se Weber e Marx estavam preocupados, acima de tudo, com a perda potencial de liberdade, por outro lado, Durkheim e seu sobrinho colocaram mais ênfase na perda do sentido e da solidariedade. No primeiro caso, a autonomização das estruturas sociais funcionalmente diferenciadas, sistematicamente coagindo os indivíduos desde fora e impondo-lhes um modo estratégico de ação, era vista como uma ameaça à autonomia individual (alienação); no segundo caso, a predominância da ação estratégica era vista como o elo para a dissolução da solidariedade (anomia).

\section{5-1973: Anti-Modernidade}

Conferindo um giro otimista à clássica interpretação da modernidade, a teoria da modernização emergida no período pós-guerra, da qual Talcott Parsons (1966, 1977) é um dos principais representantes, preconizava uma visão 
evolucionista da mudança social. De acordo com Parsons (e vários outros espíritos de comum abordagem, tais como Daniel Lerner, Marion Levy, Alex Inkeles, S. N. Eisenstadt, Walt Rostow e Clark Kerr), todas as sociedades em modernização estavam destinadas a seguir uma similar trajetória de mudanças incrementais não-revolucionárias e a experimentar um processo constante, contudo, linear de aumento geral da atualização adaptativa ("adaptiveupgrading") mediante a diferenciação e a integração funcionais de seus subsistemas. Por sua vez, tal integração permitiria ao sistema controlar mais e mais assertivamente seu meioambiente. Desde essa perspectiva evolucionista e ligeiramente teleológica, todas as sociedades eram vistas movendo-se e convergindo para 0 alto estágio do industrialismo, da secularização e da democratização - que Parsons considerava exemplificado nos Estados Unidos da América dos anos de 1960. Tal teoria da modernização oferecia não somente um esquema analítico, mas, na medida em que excluía caminhos alternativos à modernidade, constituía também uma justificação do status quo.

Decorrente de uma mudança no clima cultural, intelectual e ideológico, a teoria da modernização de Parsons foi amplamente rejeitada nos finais de 1960, não apenas por razões empíricas como também por razões ideológicas. A nova geração de teóricos críticos passou a considerar a interpretação unilinear e teleológica de Parsons sobre a história mundial como uma ardilosa ideologia velada do status quo e do imperialismo estadunidense. Enquanto a teoria da dependência rejuvenesceu o velho argumento leninista de que a prosperidade das sociedades capitalistas é adquirida às expensas do empobrecimento de amplas áreas do globo (CARDOSO; FALETTO, 2004; COCKROFT; FRANK; JOHNSON, 1972), Barrington Moore (1966) argumentou que estava propagando-se por todo 0 mundo ditadura e não democracia. Resultante desse contexto, a fábula parsonsiana de desenvolvimento crescente passou a ser tratada com ostracismo. A sua macronarrativa foi percebida como sendo eurocêntrica e, eventualmente, a teoria da evolução e modernização foi substituída por uma teoria marxista da revolução e da contrarrevolução. Alguns dos críticos de Parsons até mesmo rejeitaram sua abordagem do processo de modernização como tal. Os membros da Escola de Frankfurt, por exemplo, simplesmente inverteram o otimismo daquela teoria da modernização: as sociedades industriais-capitalistas não caminham na direção da democracia e da liberdade, mas, ao contrário, na direção do aumento da dominação e da alienação das massas. 


\section{3-1989: Pós-modernidade}

Posteriormente, nos anos de 1980, quando o entusiasmo revolucionário dos anos de 1970 desvaneceu, então, emergiu o pós-modernismo na cena acadêmica. 0 pós-modernismo radicalizou a crítica da Escola de Frankfurt sobre a razão instrumental e semeou a desistência do projeto de modernidade em termos genéricos. 0 pós-modernismo é, contudo, um conceito ambíguo e, essencialmente, contestado. Em direção a clarificar seu significado e a evitar confusão entre diferentes tipos de "pós-ismo", proponho categoricamente diferenciar (a) pós-modernismo, (b) teoria social pós-moderna e (c) pósmodernidade. Esses termos não são equivalentes, apesar disso, ocorrem em três diferentes - ainda que sobrepostos - contextos discursivos da teoria cultural, da filosofia e da sociologia nos quais se diz que teve lugar a chamada "virada pósmoderna".

\section{a) Pós-modernismo.}

0 debate sobre o pós-modernismo ganhou um importante papel no campo da teoria cultural, da estética e da arquitetura (CONNOR, 1989; HARVEY, 1989; LASH, 1990; JAMESON, 1991). Neste marco, o debate revolveu-se em torno a distinções entre modernismo e pós-modernismo nas artes. 0 modernismo era representado como a culminação do processo de diferenciação social e de autonomização, no qual a esfera estética e cada um de seus subcampos (pintura, escultura, literatura, teatro, arquitetura, cinema, etc) seguiram suas próprias leis imanentes (por exemplo, l'art pour l'art, a casa como uma máquina para viver, etc). Inovação e racionalização formal são, por este caminho, as normas do modernismo avant-garde. 0 pós-modernismo, por sua vez, reagiu contra a indicada autonomização da esfera cultural; defendeu a des-diferenciação contra 0 "Grande Divisor" entre arte popular e alta arte; considerou possível superar tais fronteiras e reconectar a esfera cultural ao mundo da vida, inclusive, até o ponto em que 0 mundo da vida - ele mesmo, invadido e colonizado por produtos mercadorizados por uma cultura de massas antiaurática - passaria a ser um aspecto da cultura pós-moderna.

b) Teoria social pós-moderna.

Os discursos sobre o pós-moderno também compareceram no campo da filosofia, da teoria social e dos Estudos culturais (HABERMAS, 1985; DEWS, 1987; BEST; KELLNER, 1991) Pós-modernistas criticaram as assunções racionalistas 
preconizadas pelas modernas filosofia e teoria social - listando desde o projeto de Descartes, Kant, Hegel, até as teorias sociais de Marx, Durkheim, Weber e Habermas, a quem eles frequentemente nomearam como os arquemodernistas cujo trabalho mereceria ser desconstruído. Filósofos pós-estruturalistas como Lyotard, Derrida, Deleuze, Baudrillard, Vattimo, entre outros, inspirados por Saussure, Nietzsche e Heidegger, de maneira variada criticaram a teoria moderna por sua premissa de uma fundação do conhecimento, por seu universalismo e caráter totalizador e, sobretudo, por seu falacioso racionalismo e logo-(se não falo)centrismo. Além disso, apresentaram uma crítica à representacionalidade e à crença moderna de que a teoria espelha a realidade. Em relação a este ponto, adotaram uma postura inspirada na posição relativista do feminismo e do perspectivismo da teoria pós-colonial. Em contiguidade, recorrentemente, combinaram tal postura com o desconstrutivismo hermenêutico, a partir do postulado de que todas as representações cognitivas sobre o mundo são mediadas histórica e linguisticamente.

\section{c) Pós-modernidade.}

Discursos sobre o pós-modernismo também compuseram a produção sociológica e político-econômica, que reivindicavam identificar uma transição da modernidade para um novo estágio histórico (HARVEY, 1989; SMART, 1992; WEBSTER, 1995). Analisando a predominância crescente das mídias e das tecnologias da informação, a ampliação do setor de serviços e de consultoria e as mudanças no regime de acumulação de capital, vários autores avançaram na reivindicação de que nós agora havíamos atingido um novo estágio histórico para além da modernidade (senão para além da história) e que nós agora viveríamos em um novo tipo de sociedade que eles variegadamente rotularam de sociedade pós-moderna, sociedade pós-industrial ou sociedade pós-fordista.

\section{Neo-modernidade}

Desde a queda do muro de Berlim, de alguma maneira, a teoria da modernização voltou a ocupar a cena e apresentou um excesso de fúria (SZTOMPKA, 1993, p. 129-141). A procrastinada "terceira onda de democracia" (HUNTINGTON, 1991), iniciada na Europa ocidental nos anos de 1970 (Portugal e Espanha), continuada na América Latina (Brasil, Argentina, Chile) e na Europa oriental (Polônia Alemanha e Hungria) nos anos de 1980, por seu curso, encontrou provisória conclusão no oriente médio através da "primavera árabe" e 
expôs que o antigo tema liberal da teoria da modernização de Parsons não havia perdido completamente sua atualidade política nem sua força ideológica. 0 livre mercado, a norma de lei e, sobretudo, a democracia parlamentar não eram apenas ideologias do status quo - como os protestos "anti" alegavam -, nem metanarrativas que eram desconstruídas - como os pós-istas afirmavam -, mas, contando com a condição de que estejam adequadamente reformulados em um esquema neofuncionalista, então, mostravam-se representar verdadeiros "universais evolucionistas" que demandavam ser institucionalizados por meios democráticos.

Extrapolando e estendendo a visão do Leste para o Ocidente e além, podemos observar que as revoltas populares contra os regimes comunistas (na Europa Oriental) e contra os regimes ditatoriais militares (na Europa Ocidental e América Latina) abriram novas perspectivas para uma global e coordenada batalha democrática por realização e institucionalização de valores pós-materialistas. Os movimentos sociais nascidos nas lutas contra regimes autoritários eram animados pelo apelo da radical democracia e combateram, com sucesso, revoluções não por socialismo, mas por democracia, solidariedade e defesa do mundo da vida. A (re)apresentação do conceito de sociedade civil do século XVIII - entendido como a autorregulação da esfera pública que faz a mediação entre, por uma parte, a esfera privada e, por outra parte, o Estado e o mercado (COHEN; ARATO, 1992) está vinculada à (re)avaliação pós-materialista do universalismo. Na medida em que não é considerado como algo essencialmente repressivo, mas como um valor vivificador da luta democrática que os novos movimentos sociais transnacionais travam contra o Estado e o mercado, nós podemos, de fato, dizer que estamos testemunhando um gradual mover de posição: desde o "pós-“ para 0 "neomodernismo".

\section{9-2007: Modernidade Tardia}

A noção de modernidade tardia é usada aqui como um significante sintético de uma teoria sociológica do global atual, que objetiva integrar aspectos das teorias da clássica, anti, pós e neomodernização em um novo quadro analítico. A teoria da modernidade, que aborda dialeticamente os limites de cada uma das teorias precedentes, oferece um esquema geral de diretrizes teóricas para a análise do duplo processo de globalização e individualização. Tal duplo processo será discutido nas partes dois e três desse artigo e será considerado formador do núcleo duro da análise na sociologia da juventude, que será apresentada na parte quatro. 
a) Inspirada pelo clássico projeto da sociologia, a teoria da modernidade tardia tem por objetivo examinar criticamente em minúcia as teorias de Marx, Durkheim e Weber para atualizá-las de maneira que ganhem relevância para 0 tempo presente. Em retrospectiva, nós podemos agora ver que a radicalização da modernidade conduziu a uma situação não prevista pelos pais fundadores. Em primeiro lugar, eles não anteciparam que a compressão das noções de tempo e de espaço levaria a um mundo global no qual os processos sociais estão interconectados econômica, política e culturalmente. Em segundo lugar, eles estavam algo demasiado otimistas quanto às prospectivas do industrialismo e não anteciparam os limites ecológicos do crescimento econômico. Em terceiro lugar, embora os pais fundadores convergissem em sua crítica ao utilitarismo e insistiram na necessidade de revigorar o tecido social, tampouco Durkheim - que levou aos limites a ameaça da anomia -, nem Marx ou Weber - que estavam mais preocupados com a ameaça da alienação - imaginaram a possibilidade de que a anomia e a autonomia seriam reunidas em uma ética pós-materialista das juventudes e nas políticas dos novos movimentos sociais.

b) Muito embora a análise sociológica da modernidade tardia seja definitivamente pós-marxista em inspiração, o prefixo "tardia" é intencionalmente usado aqui com um tipo de tributo à análise neomarxista do "capitalismo tardio" (ADORNO, 1972). A série de crises que enxameou a semi-periferia do sistemamundo desde os anos de 1980, alcançou agora o centro deste sistema. A crise financeira no sistema de crédito de 2007-2008, a qual levou a uma crise fiscal que atingiu a Europa, mostra-nos que o capitalismo não é tão seguro quanto se inculcou. Embora o capitalismo industrial esteja já agora espraiado por todo 0 mundo, como previa Marx e Engels no Manifesto do Partido Comunista, a sociologia da modernidade tardia invalida a afirmação de que não há alternativa factível em relação ao livre mercado como peça da ideologia neoliberal e de seu ataque ao Estado. Analisando criticamente as radicais transformações econômicas, políticas e culturais pelas quais as sociedades do mundo todo estão passando, a teoria da modernidade tardia objetiva explorar as possibilidades para emergência de novos movimentos sociais transnacionais que interpelariam as consequências sociais da hegemonia neoliberal.

c) A sociologia da modernidade tardia definitivamente não é uma sociologia pós-moderna. Abandonando quaisquer atrações da teoria social pós-moderna, ela trabalha, ao contrário, na direção de um sociológico cotejamento do pósmodernismo e da pós-modernidade. Precisamente, a sociologia da modernidade tardia concorda com os pós-modernistas quanto à cultura de massas contemporânea ser, essencialmente, pós-moderna, entretanto, contra eles, ela 
vincula 0 regime de significação pós-modernista ao regime de acumulação pósfordista e, por este caminho, decodifica o pós-modernismo como uma expressão cultural do modernismo tardio e um produto cultural resultante do modernismo tardio. Cabe salientar que a sociologia da modernidade tardia rejeita categoricamente 0 posicionamento fideicomisso, antissistemático e antifundamentológico da teoria social pós-moderna (VANDENBERGHE, 1996).

Contudo, na medida em que a teoria da modernidade tardia transforma a teoria social pós-moderna de possível fonte conceitual em tópico da análise sociológica, por consequência, ela transpõe o ceticismo dos filósofos pósmodernos por dentro do mundo da vida e reposiciona assim a crítica pósmoderna da autoridade dentro do fulcro da crítica social das políticas da sociedade industrial. Em continuação aos esforços pós-modernos para delinear a origem de importantes mudanças e deslocamentos movediços sejam eles sociais, econômicos, políticos e/ou culturais ocorridas nas últimas décadas, por sua vez, a teoria da modernidade tardia, divorcia-se da postura foucaultiana quanto ao radical descontinuismo. Ao invés de propalar afirmações apelativas pseudohistóricas sobre um mover epocal para além da modernidade, a teoria da modernidade tardia analisa a pós-modernidade como uma radicalização da modernidade e nega-se a minimizar a força contínua do capitalismo.

d) Uma vez que a interpretação pós-modernista do mundo como um local privatizado e fragmentado confere preferência a uma análise das forças econômicas que desfiguram o mundo global e das forças políticas que buscam reconfigurá-las, por outra parte, a teoria da modernidade tardia acompanha de bom grado a teoria da neomodernização pelo fato da alocação da questão da democracia de volta à centralidade da agenda. A discussão sobre modernização reflexiva, individualização, juventudes e os novos movimentos sociais, que apresentarei na última parte deste artigo, está de acordo com esta última perspectiva e está circunscrita como uma proposta de contribuição ao conjunto deste debate.

\section{GLOBALIZAÇÃO ECONÔMICA, POLÍTICA E CULTURAL}

\section{O que é globalização?}

o Pós-modernismo foi a mania dos anos de 1980. Desde o início dos anos de 1990, a teoria da globalização tornou-se cada vez mais um influente paradigma. De fato, essa discussão pode ser considerada "a sucessora dos debates sobre modernidade e pós-modernidade" (FEATHERSTONE; LASH, 1995, p. 1). 
Globalização refere-se aos processos sociais de "compressão tempo-espaço" (HARVEY, 1989, p. 240) nos quais as "restrições da geografia em relação aos arranjos sociais e culturais retrocedem e as pessoas tornam-se cada vez mais consciente desse retrocesso" (WATERS, 1995, p. 3). Enquanto as noções de tempo e espaço tornam-se separadas do contexto local e padronizadas por mapas e relógios, por outra parte, indivíduos estão aptos a se comunicar através de distâncias espaciais e temporais. 0 mundo "encolhe-se" e as fronteiras se apagam (para aqueles que tem um bom passaporte , recursos para viajar e se comunicar, etc.). A intensificação de relações sociais mundializadas, dizia Giddens, conecta localidades distanciadas de tal maneira que acontecimentos locais são influenciados por eventos que acontecem a milhares de milhas de lá e vice-versa (GIDDENS, 1990, p. 64). Enquanto o global e o local tornam-se dialeticamente entrelaçados, ações locais e estruturas globais tornam-se, portanto, mutuamente implicadas de tal maneira que ações locais reproduzem ou transformam estruturas globais nas quais elas estão encravadas e pelas quais elas são cada vez mais condicionadas.

Uma vez transposta do terreno metateórico para o terreno sócio-histórico, o dialético jogo interno entre ação e estrutura, conhecido como "estruturação", então, ganha uma dimensão global. Da mesma forma que todo ato de fala individual pressupõe a instituição social da linguagem e contribui para sua reprodução ou transformação, nessa perspectiva, toda ação local é potencialmente condicionada por estruturas globais e implicada em sua reprodução ou transformação. As questões importantes a levar ao limite aqui são estas referentes ao fato de que a dialética entre o global e o local não têm um, porém dois lados: estruturas globais afetam ações locais, todavia, na medida em que estas pressupõem aquelas e dependem daquelas, assim, as ações locais podem obter significativos impactos sociais e políticos em estruturas globais.

As análises da multiplicidade de vínculos e de conexões, que transcendem 0 Estado-nação e fazem emergir o sistema mundial, vieram a ocupar o centro das ciências sociais e suas tentativas para teorizar a globalização (ALBROW, 1996; AXFORD, 1995; BECK, 1997, 1998a, 1998b; FEATHERSTONE, 1990; FEATHERSTONE; LASH, 1995; McGREW, 1992, 1997; ROBERTSON, 1992; WATERS, 1995). Embora alguns campos de debates estejam ainda debruçados sobre a questão da periodização do início da virada global, todos os protagonistas do debate sobre a globalização estão em consenso quanto ao fato de que 0 alcance (ou o "alargamento") e a intensidade (ou a "profundidade") dos processos de inter e de transnacionalização ganharam significativo aumento nas últimas décadas, com o resultado de que uma civilização universal está ao ponto de 
eclodir. Objetivamente, os sistemas culturais, políticos e econômicos estão interconectados e interdependentes como nunca antes; subjetivamente, estamos ampliando a consciência do mundo como um todo. Enquanto os produtos da mídia circulam em uma arena internacional, a humanidade está apta, em um sentido, a observar a si mesma em tempo real. Já agora, passando a um ponto de vista algo especulativo, falando nos termos do antigo Hegel, poderíamos referir como "globalização an sich" o lado objetivo e o lado subjetivo como "globalização für uns". A partir de esse ponto, poderíamos sugerir que a interconexão corrente entre coisas e pessoas é o gatilho de um processo global de morfogênese no qual sociedade, cultura e personalidade são todas transformadas ao mesmo tempo em direção à "globalização an sich und für uns".

No mapa, todavia, as fronteiras entre países estão tão claras como nunca. Não obstante, um olhar de perto sobre as contemporâneas interconexões econômicas, políticas e culturais revelam que essas fronteiras estão tornando-se amplamente porosas e permeáveis, quase ao ponto de tornarem-se irrelevantes pelo menos no Ocidente, uma vez que o fenômeno da globalização não é experienciado e significado uniformemente através do globo. Imensos "fluxos de capital, dinheiro, bens, serviços, pessoas, informação, tecnologias, políticas, ideias, imagens e regulações" (LASH; URRY, 1994, p. 280) transcendem Estados-nação individuais e dissolvem as suas fronteiras físicas e mentais. Localmente ligados os pés ao solo, indivíduos podem pensar, sonhar, investir e comunicar globalmente sem que exista a menor dificuldade proveniente das fronteiras. Em pouco tempo, pensar globalmente não será mais privilégio de diplomatas, astronautas e banqueiros. Para os jovens que crescem com e são socializados pela televisão e a Internet, desde o mais tenro início, a sociedade é experienciada como uma "sociedade global" menos clivada por fronteiras do que mais. Esse quadro não significa que os lugares perderam sua importância. Ao contrário. Porém, que eles sejam cientes ou não, o fluxo da consciência ganha uma dimensão global.

Os processos de globalização estão conduzidos na dianteira pela economia. 0 globo inteiro está operando dentro de uma única economia capitalista mundial. 0 fluxo econômico de capital, de mão-de-obra, de mercadorias, de informação e de imagens atravessa as bordas sem que se tenha controle suficiente (infra, Globalização da economia). A expansão do mercado mundial capitalista está acompanhada pelo declínio do Estado-nação e de seu poder de controle sobre 0 fluxo de bens, pessoas, informações por várias formas de expressão culturais. Relações entre atores não-governamentais como, por exemplo, organizações internacionais, corporações transnacionais e movimentos sociais transnacionais, 
já agora, suplementam relações intergovernamentais entre Estados-nação (infra, Globalização da política).

Além do desenvolvimento de uma economia global capitalista e de um deslocamento enfraquecedor do Estado-nação, a ascensão da cultura global configura uma característica saliente apresentada pela globalização contemporânea. A cultura global é ambígua: envolve a difusão universal dos produtos culturais do capitalismo e a extensão da ideologia consumista assim como, não obstante, contém em si a interpelação local na interpretação daqueles produtos culturais globais (infra, Globalização da cultura). Culturas globais e produtos culturais em realidades locais, colonizando-as, tanto quanto provendo forças de resistência contra tal colonização. Em todo caso, culturas globais produzem reflexividades individuais, por consequência, compostas por propriedades específicas: indivíduos confrontados com o arco do possível quanto a formas e estilos de vida, escolhem, fabricam e remanejam o arranjo de suas próprias biografias. Ao construírem tais escolhas conscientemente, circunscrevem o local entrelaçando-o dialeticamente com o global, então, chegamos ao ponto no qual visualizamos o fato de que a agremiação das escolhas da vida privada podem produzir implicações políticas intrinsecamente agregadas, como veremos detidamente mais à frente quando analisarmos a conexão, nessa perspectiva, entre juventude e movimentos sociais.

\section{Globalização da economia}

Embora 0 impacto das forças da globalização sejam mais fortemente sentidos no domínio do econômico, é importante considerar o processo de globalização como um fenômeno multidimensional e evitar reduzi-lo somente à sua dimensão econômica. A globalização não pode estar somente sobre a expansão do livre trade e da competitividade em um mercado global, mas envolve um processo de mudança social total pelo qual o local e o global são mutuamente imbricados. Aqueles economistas que levam às últimas consequências a dimensão econômica da globalização às expensas das demais dimensões, tais como as política, ecológica, civil, legal, cultural e pessoal, não podem ver as implicações políticas e ideológicas de suas análises. $\mathrm{Na}$ medida em que seus modelos, sistematicamente, ignoram as condições extra-econômicas do livre mercado, eles endossam e, performativamente, reforçam a ideologia neoliberal de acordo com a qual as leis do livre mercado representariam, atualmente, o único modo possível de governança global. 
Contudo, se nós adotarmos as perspectivas política e sociológica para, no mesmo passo, submetermos as leis econômicas do livre mercado global a uma análise crítica, então, veremos que aquelas leis apenas se aplicam à condição na qual elas estejam livres de intervenção reguladora e que nada seja feito que impinja na clausura do sistema. A análise das mencionadas condições extraeconômicas da clausura do sistema econômico desfetichiza as leis de mercado e revela que o neo-liberalismo não é simplesmente uma doutrina econômica, mas envolve um projeto político. Aliás, como disse Bourdieu, "neoliberalismo é um programa científico de conhecimento convertido em um programa político de ação que aspira a criar as condições de realização de sua 'teoria' mediante a destruição metódica das estruturas coletivas aptas a atrapalhar a lógica do mercado puro." (BOURDIEU, 1998, p. 109).

Ao passo em que o neoliberalismo somente reconhece indivíduos, então, a realização política de sua teoria econômica envolve a sistemática atomização do social, isto é, a redução de estruturas coletivas para explorar indivíduos estrategicamente competindo por escassos recursos. Como um resultado do desmantelamento das estruturas coletivas, indivíduos - e especialmente os jovens - tornam-se um manipulável e exploratório fator de entrada contribuinte à produção do sistema econômico. Embora o tipo ideal de uma economia de livre mercado verdadeiramente globalizada não exista ainda realizado na prática (HIRST; THOMPSON, 1996), o "mito da globalização" é constantemente invocado pela "classe capitalista transnacional" (SKLAIR, 1991, p.70-72, p.133-137) como uma arma para flexibilizar 0 processo de produção e para desestabilizar 0 mercado de trabalho.

0 argumento é sempre o mesmo: para permanecer competitivo em uma escala mundial, a produtividade marginal do trabalhador tem de ser elevada e isto somente é possível a partir de três procedimentos: (1) pela redução dos custos de trabalho, o que implica no desmantelamento do Estado de bem-estar social; (2) pela substituição de trabalhadores por equipamentos capitais, o que significa a introdução de novas tecnologias e (3) pela racionalização do trabalho, o que suporta a flexibilização da sua organização. Em todos os casos, um provável resultado da implementação das políticas neoliberais segue na direção de uma "sociedade dual" global com benefícios recordes para os vencedores da globalização - é "global” quem é versátil - e o mais e mais profundo desemprego de massa para os perdedores - é "local" quem é confinado ao seu pedaço de terra (BAUMAN, 1998, p. 6-26). A desigualdade aumenta, a exploração também e o que se apresenta como governança não-política de mercado, de fato, equivale a uma mascarada politização da sociedade por um apelo às irresistíveis forças do 
mercado global. Apesar de que os efeitos da globalização econômica afetam pessoas de todas as idades, atingem mais claramente os jovens que estão especialmente vulneráveis às estratégias capitalistas de flexibilização global da força de trabalho. Continuamente confrontados com o prospecto do desemprego, eles estendem seus estudos, tornam-se flexíveis, trabalham no mercado de trabalho informal, aceitam pagamentos parcelados e inferiores, assim como variáveis horas de trabalho e, por fim, acabam por culpar a si próprios se não lograrem assegurar uma posição estável no mercado de trabalho.

\section{1) Desmantelamento do Estado de bem-estar social}

Empresas multinacionais e corporações transnacionais organizam em uma base global sua produção, marketing e distribuição. Suas atividades são predominantemente adaptadas para aumentar sua lucratividade e maximizar sua internacional posição competitiva. Na medida em que subsidiárias nacionais operam no contexto de uma estratégia corporativa totalizante, rótulos nacionais literalmente perdem sua significação e tornam-se fetiches, no sentido marxista da palavra, disfarçando no idioma do controle nacional e da soberania territorial a transnacional acumulação de capital e a internacional divisão de trabalho (APPADURAI, 1990, p. 306-307). Organizada dentro de o esquema modelar da divisão internacional do trabalho, a produção é cingida em fragmentos e assignada a não importa qual parte do mundo, contando que tenha provido a mais lucrativa combinação entre capital e trabalho. Por esta razão, a produção é deslocalizada e a matriz é instalada onde os custos de trabalho são minimizados. 0 resultado é não somente a ocupação pelas empresas da posição de jogar os Estados-nação um contra o outro e assim barganhar por incentivos fiscais, oportunidades infraestruturais e subvenções, mas também colocar os governos nacionais sob a pressão pelo desmantelamento do Estado de bem-estar social e pela abolição dos direitos trabalhistas. Dessa maneira, o capital transnacional torna-se, cada vez mais, genuinamente solto e, no mesmo passo, solapa a democracia e o Estado de bem-estar social: deslocalizando sua produção, cria desemprego massivo na nação da qual é proveniente e o faz mediante sistemáticas externalidades. Todo esse processo está desenvolvendo-se sem passar por discussão no parlamento, sem decisões por governos e sem alteração na legislação, chegando ao ponto do que Beck denomina "subpolitização global" da sociedade, "politizar a sociedade no decorrer de uma despolitização do Estado" (BECK, 1997, p. 176). 
2) Introdução de novas tecnologias.

Em 1974, Daniel Bell prognosticou a chegada da "sociedade pósindustrial", uma sociedade diante do "princípio axial" do conhecimento e dominada pela economia dos serviços. Ao comparar a sociedade pós-industrial à industrial, que é dominada pela manufatura, Bell identifica cinco mudanças maiores (BELL, 1974, p. 14-33): i) as fontes de inovação são derivadas, majoritariamente, da pesquisa científica e do desenvolvimento tecnológico. ii) Enquanto o desenvolvimento de ciência e tecnologia estimula 0 crescimento econômico, por outro lado, o crescimento tecnológico é, já agora, ele próprio, controlado e sistematicamente planejado. iii) uma relativa troca de ênfase ocorreu da produção de bens para a provisão de serviços técnicos e humanos. iv) por consequência, conduziu a uma mudança na estrutura ocupacional, o que é indicado pelo crescimento em número e em influência de uma classe de técnicos e profissionais. Finalmente, v) o mais sênior dos trabalhadores de serviço, tornase a classe dominante da nova sociedade. Eles dominam porque controlam 0 saber teórico e planejam o desenvolvimento futuro. Bell é muito otimista sobre 0 crescimento das oportunidades de emprego na sociedade pós-industrial. De acordo com seu prognóstico, a sociedade dos serviços criaria uma oferta contínua de oportunidades de trabalho nos serviços voltados para satisfazer as novas necessidades que geram mais riqueza.

Um quarto de século mais tarde, o prognóstico otimista de Bell deu-se a ver putrefato, em grande parte. Jeremy Rifkin indica que no passado, quando as novas tecnologias substituíam trabalhadores em um determinado setor, novos setores emergiam para absorver os operários dispensados. Hoje, no entanto, todos os três tradicionais setores da economia - agricultura, manufatura e serviços - estão vivenciando um processo de substituição pela tecnologia. Por contiguidade, observamos que as ocupações de colarinho branco, constituintes do setor de serviços, estão elas próprias automatizadas e tornando-se redundantes. Enquanto este setor está crescendo, não supõe absorver mais do que uma fração das centenas de milhares que serão eliminadas nas próximas várias décadas do despertar dos avanços nas ciências da informação e da comunicação (RIFKIN, 1995, p. 17).

3) Racionalização flexível do local de trabalho.

Teóricos da Escola de Regulação Francesa como Aglietta, Boyer e Lipietz, ponderam que por volta da metade da década de 1970 o regime fordista de acumulação de capital tornou-se insustentável (AMIN, 1994; BOYER e SAILLARD, 
2002; HARVEY, 1989; LASH; URRY, 1987). Devido à excessiva acumulação, o quarto Kondratieff ou a quebra da longa onda de crescimento econômico por volta de 1973, a economia mundial entrou em uma séria crise. 0 problema principal quanto ao modelo fordista de produção em massa, o qual estava organizado em torno da linha de montagem, era a inflexibilidade. A produção em massa de bens padronizados, a natureza centralizada da posição de tomada de decisão e a simplificação das tarefas de trabalho levou a uma redução do montante de competências, necessárias à execução de uma particular atividade profissional, que desmotivou a força de trabalho e a fez inapta para atender rapidamente as transformações das demandas de mercado.

0 modelo pós-fordista inverteu aquelas características (CROOK; PAKULSKI; WATERS, 1992, p. 167-196; WEBSTER, 1995, p. 135-162). Para adaptar-se à incessante transformação da demanda de mercado, o modelo pós-fordista projeta novos e diversificados produtos constantemente. Dirigido por conhecimento e informação, este é essencialmente um modo de produção pós-industrial, o qual segue da padronizada produção em massa de bens similares para a segmentada produção de mercadorias diversificadas. 0 cambio de uma "economia de escala" (produzindo grandes quantidades de produtos padronizados de maneira a financiar altos níveis de investimento de capital) para uma "economia de escopo" (produzindo uma gama imensa de mercadorias diferentes entre si) desenvolveuse junto à e obteve condições de possibilidade pela radical flexibilização da organização da produção seguindo as linhas gerais do modelo japonês ("toyotismo").

Primeiramente, a linha de montagem desaparece e é substituída pelo trabalho em equipe. 0 processo de produção é dividido no seio de numerosos estágios previamente estabelecidos, cada qual organizado em torno às equipes de trabalho. Os trabalhadores são polivalentes, qualificados e alternam-se de uma tarefa para outra. Uma vez que a extrema especialização característica do fordismo é substituída pela especialização flexível, então, os trabalhadores são requalificados (reskilled). Hábeis e adaptáveis, eles são capazes de se adaptar a uma multiplicidade de tarefas variáveis e de produzir continuamente uma gama expansível de diferentes produtos altamente especializados.

Em segundo lugar, a posição de tomada de decisão passa a ser descentralizada e a hierarquia aplainada. As estruturas de comando centralmente controladas, verticalmente integradas e burocraticamente organizadas são substituídas por um fluxo horizontal de informações entre todos os elementos da rede de trabalho envolvida no processo de produção. 0 aplainamento da pirâmide 
organizacional tradicional torna as posições de trabalho intermediárias supérfluas, a exemplo de gerentes intermediários que eram responsáveis por atividades como a de coordenar 0 andamento do fluxo de trabalho na escala organizacional. Eles entram agora na estatística de desempregados. A forma extrema da descentralização gerencial é atingida quando corporações verticalmente desintegram e subcontratam terceiros para prover, tanto quanto possível, os requisitos da empresa.

A estratégia de externalizar custos mediante a terceirização das atividades ajusta-se à estratégia corporativa global de "enxugamento", que atua reunindo as estratégias de flexibilidade do salário (individualização dos salários, desassociando-os dos acordos corporativos entre 0 empregador e os sindicatos), de flexibilidade do trabalho (regulamentação por termos singularmente fixados em contrato) e de flexibilidade do tempo (trabalho por regime de horas parceladas). Por sua vez, a crescente competição por escassos empregos entre os membros do exército de reserva tende a pressionar os salários para baixo e a elevar significativamente a taxa geral de flexibilidade das organizações para obterem a permanência nas melhores posições de competitividade em relação à economia global. Nesse quadro, a face da estratégia de "flexploração" (BOURDIEU, 1998, p. 99) do capitalismo "desorganizado", a mesmo tempo, guarda em si 0 fato de 800 milhões de seres humanos atualmente desempregados ou subempregados no mundo - 0 mundo passível de ser lido como um sinal do definitivo fim de uma forma social baseada no trabalho e na utopia do pleno emprego (OFFE, 1985a, p. 129-150).

\section{Globalização da política}

Como resultado da multiplicação e intensificação dos laços econômicos, políticos e culturais e das interconexões tecnológicas através das fronteiras, o Estado- nação tende a perder a importância que um dia teve. 0 Estado-nação é crescentemente reduzido a ser uma possível forma organizacional entre outras. Por conseguinte, a teoria clássica da "sociedade do Estado-nação" (ALBROW, 1996, p. 118), que erroneamente identifica Estado-nação e sociedade, está descartada. Embora o processo global não deva ser exagerado com a finalidade de representar um eclipse total do Estado-nação, tampouco a simples emergência de uma sociedade global integrada, provavelmente, justificaria 0 abandono do postulado implícito do "nacionalismo metodológico", que caracteriza a sociologia clássica e requer uma reformulação do foco do projeto sociológico - desvinculá-lo 
da unidade de análise sociedade e Estado nacional para direcioná-lo à observação da emergência de uma sociedade mundial.

Tal redirecionamento do projeto sociológico envolve uma criativa cooperação entre as disciplinas da Sociologia, Economia Política Internacional e Relações Internacionais. Se a disciplina das Relações Internacionais, entendida como um segmento internacional da Ciência Política e tradicionalmente dedicado às relações diplomáticas entre Estados; e a Economia Política Internacional, entendida como um segmento das Relações Internacionais ao qual concerne a análise dos caminhos pelos quais a política internacional forma ou é formada pela economia global, então, essas duas disciplinas poderiam contribuir para a Sociologia mediante a adição dessa dimensão internacional a ela. Sendo assim, eu gostaria de pensar que a Sociologia pode, por sua parte, enriquecer a disciplina das Relações Internacionais a partir de sua análise da coerência dialética entre, por um lado, ação e estrutura e, por outro, a localização da importância dos movimentos sociais na transformação das estruturas sociais.

Nessa direção, está pressuposto, todavia, que o Estado nacional não é mais considerado como unidade de análise, mas que as redes e os laços internacionais entre pessoas, para além das fronteiras, são analisados como a base da emergência de movimentos sociais transnacionais que podem interpelar a marcha atual da globalização mediante uma revisão radical de suas premissas subjacentes. Em outras palavras, em uma perspectiva sociológica sobre a globalização da política, os movimentos sociais transnacionais são considerados como forças transformativas que fazem a mediação entre os mundos da vida locais e o sistema global. Por coordenar internacionalmente a pressão moral sobre os sistemas políticos nacionais e, principalmente, pelo que Habermas denominou "políticas domésticas transnacionais" (HABERMAS, 1998a, p. 78), os movimentos sociais reivindicam organismos supranacionais de governança ou apelam aos organismos semelhantes existentes para regular, domesticar e finalmente reorientar o processo de globalização na direção pós-materialista de uma ordem democrática de "governança humana” (FALK, 1995) justificável socialmente, politicamente, moralmente e ecologicamente. A questão não é estabelecer um governo-mundo que 're-regularia' as economias desreguladas, mas forçar os governos nacionais a levar em conta demandas por governança humana, vindas dos mundos da vida transnacionais interconectados, de tal maneira que as funções do Estado de bem-estar social - que até agora eram executadas pelos Estados-nação e que foram solapadas pela globalização econômica - possam estar garantidas por instâncias supranacionais. Dado que a União Europeia não é somente um mercado unificado, mas envolve um projeto político e social, faz 
ganhar sentido projetar a ideia de um Estado de bem-estar social supranacional, legitimado democraticamente, como o estágio final do processo de unificação europeia (BOURDIEU, 1998, p. 66-75; HABERMAS, 1998b, p. 134-156).

No final do século XX, a política já não pode mais ser concebida como uma insular atividade social nacional. A divisão tradicional entre política doméstica e internacional tornou-se embaçada e, eventualmente, vazia. Por conseguinte, as assunções estado-cêntricas da teoria tradicional de relações internacionais - a qual privilegia a soberania territorial dos Estados-nação e o considera unidade de análise primária - estão chegando ao seu esgotamento (ROSENAU, 1990). As razões para o esvaziamento do estado-centrismo podem ser esboçadas nos argumentos seguintes (HELD, 1991, p. 205-209; 1995, p. 89-96).

Com o aumento em interconectividade global, as fronteiras entre Estados tornaram-se permeáveis e, cada vez mais, perderam a capacidade de gerar instrumentos políticos hábeis para controlar as transações entre pessoas, bens e serviços, tecnologia, dinheiro e informação dentro e além das fronteiras. 0 poder do Estado se reduz, ainda mais, pelo crescimento em escala e em número dos atores e processos tanto transnacionais como internacionais. Corporações transnacionais são, por exemplo, maiores e mais poderosas que alguns governos nacionais. Muitas das áreas tradicionais de responsabilidade do Estado (defesa, comunicação, gerenciamento econômico) devem, portanto, ser coordenadas em bases intergovernamentais e internacionais. Por conseguinte, os Estados foram obrigados a render sua soberania a amplas unidades políticas (União Europeia, Mercosul, blocos asiáticos), tratados multilaterais (Opec, Nato, Alca, etc.) ou organizações internacionais (Banco Mundial, Fundo Monetário Internacional, etc.).

0 resultado foi a emergência de um sistema de governança global e sua própria política de desenvolvimento e administração, que redefine e encurta 0 poder do Estado. Tal quadro fornece as bases para a emergência potencial de um Estado supranacional regional (por exemplo, União Europeia) com poder coercitivo e legislativo. Embora tal governo transnacional seja mais necessário do que nunca, mesmo que apenas para controlar as corporações transnacionais e a política de "despejo social" que delas advém, ainda não existe. Contudo, na medida em que mais e mais pessoas estão conectadas através das fronteiras e desenvolvendo relacionamentos baseados em interesses e preocupações comuns (os direitos humanos, o meio ambiente, etc), paulatinamente, uma sociedade civil global está emergindo, sendo, pois, ela própria, pré-condição para uma democracia cosmopolita em nível global. Para regular o mercado financeiro e 
controlar o poder das corporações transnacionais, faz-se cada vez mais necessária uma forma de governo transnacional. A crise financeira demonstra, porém, o quanto é elusiva a perspectiva de uma regulação global do capitalismo. Neste momento, já agora no ano de 2014, nem o colapso da União Europeia, modelo de um Estado cosmopolita possível, pode ser totalmente excluído.

\section{Globalização da cultura}

Não é necessário pensar nos termos do materialismo histórico para observar que a expansão mundial do capitalismo impacta a superestrutura. Sequer é suficiente encerrar a análise no fato de que, inelutavelmente, a cultura de massas tornou-se uma mercadoria, aliás, ao fim e ao cabo, uma mercadoria. As indústrias culturais possuem, acima de tudo, um unívoco propósito: vender, e o que se vende melhor são as artes comercialmente pasteurizadas de diversão. Para conferir isto, basta ligar a televisão brasileira no horário nobre. Em relação ao indicado ponto de referência, em todo caso, o valor de uso dos produtos culturais tornou-se secundário; o que conta é seu valor de troca e a acumulação de capital. A este respeito, produtos culturais não são significativamente diferentes de outras mercadorias. De acordo com a datada reflexão de Horkheimer e Adorno (1986), os processos de produção na indústria cultural são modelados obedecendo à produção fabril fordista. Tudo é padronizado, racionalizado, coordenado e planejado até 0 último detalhe. Todos os produtos contracenam com o espectro tanto da mediocridade como da semelhança. Objetivando esconder a identidade abstrata das mercadorias culturais produzidas em massa, a indústria cultural tenta serialmente diferenciá-los selando-os com alguma afeição de originalidade.

Enquanto Adorno e Horkheimer derivam a homogeneização dos produtos culturais de uma "tese de mercadorização da cultura", Herbert Schiller (1969) ancora a tese da mercadorização em uma análise da economia política global dos meios de comunicação de massas e a apresenta em uma "tese da americanização da cultura". Os setores de comunicação e de informação são oligopolísticos e amplamente controlados por conglomerados americanos, os quais perseguem suas estratégias corporativas na arena global. Schiller argumenta que o sistema americano de transmissão televisivo, completamente banhado pelos interesses comerciais dos conglomerados transnacionais de meio de comunicação de massas, tem servido como modelo para o desenvolvimento de sistemas de transmissão televisivo por todo o mundo, especialmente no terceiro mundo. Dados os custos enormes da produção própria, programas televisivos americanos são importados massivamente nos países terceiro-mundistas. 
0 resultado de tal "despejo cultural" é uma "invasão eletrônica global" (SCHILLER, 1969, p. 79-109) que massivamente infunde a ideologia cultural do produtivismo e consumismo em culturas locais e os coloca sob "cercamento eletrônico" que ameaça seriamente a integridade da dinâmica cultural das respectivas sociedades. Literalmente colonizando os mundos da vida locais com produtos culturais ocidentais, o sistema global de comunicação, de propriedades privadas, concentradas nas mãos de um pequeno número de conglomerados transnacionais, propõe ostensivos padrões uniformes de mídias de massas e modelos consumistas de vida que, por consequência, solapa as culturas locais, produzindo o efeito da propalada americanização dos Outros.

Por mais convincentes que possam soar os argumentos neo-marxistas, contudo, são duplamente unilaterais. Em primeiro lugar, não levam em conta suficientemente a extensão na qual o movimento socioeconômico do fordismo pós-industrial é correlato a um movimento socioeconômico do pós-modernismo. Em segundo lugar, falham ao considerar o impacto local da cultura global e, por consequência, não apreendem o modo como as culturas ocidentais estão em contato com outras sociedades mediante dinâmicas que, aparentemente estáticas, tendem a "nativizar" os produtos culturais por uma ou outra maneira.

A cultura de massas contemporânea está cada vez mais mercadorizada, todavia, isso não significa padronizada ou homogeneizada. Ao contrário, a mercadorização leva à diversificação e à heterogeneidade. A cultura de massas atual é pluralista, heterogênea, fragmentada e diversa - ou pós-moderna, para dizer em uma palavra que sumariza o processo. Na medida em que a pósmodernização da cultura é homóloga à sua mercadorização, o pós-modernismo e seu "regime figural de significação" solicita ser analisado e entendido nos termos da globalização econômica e sua acompanhante, a correlacionada mudança do regime de acumulação fordista ao pós-fordista (LASH, 1990, p. 37-52, p. 172198).

Lash e Urry demonstraram que as indústrias culturais eram "pós-fordistas avant la lettre" (LASH; URRY, 1994, p. 123). Mesmo no apogeu do fordismo, as indústrias culturais eram dirigidas pela inovação e intensiva expressão mediante design. Confrontados com a crise da super-acumulação, os demais setores da indústria seguiram a trilha pós-fordista que as indústrias culturas deixaram traçadas desde os anos de 1970. 0 que está sendo crescentemente produzido e consumido nos dias de hoje não são objetos materiais, mas objetos semióticos ou signos. 0 design dos produtos de consumo se tornou mais e mais importante. Como resultado, os objetos são cada vez mais esteticizados e, paradoxalmente, 
esvaziados de seu conteúdo material. A forma estética separa-se e coloca-se em posição hierárquica superior ao conteúdo material. 0 valor de uso tornou-se secundário e, ao final, tudo se passa como se o valor de troca induzisse a valor de uso. Além disso, conforme Baudrillard postulara, o valor de troca simplesmente absorve 0 valor de uso, tornou-se auto-referencial e adquiriu a qualidade de um simulacro, isto é, uma cópia sem original (BAUDRILLARD, 1972, 1985). Embora a influente teoria da "hiperrealidade" de Baudrillard, primeiro jocosamente e depois cinicamente, tenha exagerado o alcance da desmaterialização da realidade, não resta dúvida quanto ao fato de que a espetacularização (Debord), aliás, caracteriza a cultura de consumo contemporânea. Nesse sentido, Jameson está certo quando define o pós-modernismo como a "lógica cultural do capitalismo tardio" (JAMESON, 1991).

Por outro lado, a tese antes referida do imperialismo cultural estadunidense é problemática. Não apenas porque competitivos centros de meios de comunicação de massa emergiram na Europa, na América Latina e na Ásia, mas porque permanece apenas no âmbito global da análise de uma economia política dos conglomerados transnacionais e fracassa ao se negligenciar os processos locais de interpretação das mensagens midiáticas difundidas globalmente. A indicada tese assume, por exemplo, que soaps (telenovelas) como Dallas e Dynasty são em todo lugar interpretadas da mesma maneira e não observa que as mensagens culturais emanadas diretamente "dos EUA" são lidas e decodificadas diferenciadamente.

Analisando a hermenêutica dialética da difusão global e da recepção local das mensagens culturais, John Thompson corretamente enfatiza que "a apropriação dos produtos dos meios de comunicação de massa é sempre um fenômeno local, no sentido que envolve indivíduos específicos situados em um particular contexto histórico-social fazendo uso dos seus recursos disponíveis para conferir sentido às mensagens midiáticas e, somente então, incorporando-as às suas vidas." (THOMPSON, 1995, p. 174). A globalização e a localização das mensagens culturais são, por esta razão, não-exclusivas. As tendências a caminho da homogeneização e da heterogeneidade coexistem; são complementares e mutuamente penetradas. A globalização não equivale à deslocalização, mas pressupõe relocalização do mesmo modo como a homogeneização da cultura caminha de mãos dadas ao seu contrário, a irredutível nativização. Para superar a oposição entre globalização e localização, homogeneização e heterogeneização, Robert Robertson cunhou o conceito de "glocalização", entendido como a institucionalização global e a construção de particularismos locais (ROBERTSON, 1995). 
Atualmente, as multinacionais levam em conta características locais em suas estratégias globais de marketing. Bens e serviços são feitos sob medida e anunciados de tal maneira que se sintonizam com tradições locais. Já os produtos locais não-ocidentais são eles mesmos crescentemente vendidos e exportados para 0 ocidente. Liquidações de diversidade. Marcas ocidentais são exportadas para 0 terceiro mundo e produtos exóticos do terceiro mundo são exportados para 0 ocidente. 0 impacto das culturas não-ocidentais no ocidente não pode ser subestimado. É suficiente pensar sobre um fenômeno como 0 "boxe tailandês por garotas marroquinas em Amsterdam, rap asiático em Londres, pão irlandês, tacos chineses e o Carnaval nos Estados Unidos." (PIETERSE, 1995, p. 53) para sublinhar a questão. Como resultado da bidirecionalidade dos fluxos transnacionais, a oposição entre 0 centro cultural e a periferia tende a perder sua utilidade.

De todo modo, a cultura não pode mais ser pensada como atada territorialmente, originando-se de um processo de socialização que é localizado. As lições dos estudos culturais e pós-coloniais (Spivak; Bhabha; Gillroy; Hall; Canclini; etc.) devem ser ouvidas e endossadas: a cultura é plural, culturas desenvolvem-se, são interconectadas, interpenetradas e misturadas. A visão relativista das culturas como um mosaico de unidades com limites bem definidos e de igual valor necessita ser dinamizada dialeticamente em uma visão de "um fluente mosaico no qual as culturas derramam e se misturam." (FRIEDMAN, 1995, p. 85). A "hibridização" e a "contaminação" entre as culturas resultantes não é simplesmente "multi-cultural", mas "intercultural". Em um mundo onde 0 local e 0 global estão entrelaçados, a cultura torna-se também "glocal". Como as culturas locais são interconectadas com a global elas são, em um sentido, "subculturas dentro de um vasto todo" (HANNERZ, 1990, p. 237) ${ }^{6}$. Resultado da referida hibridização cultural, também a imaginação alça voo global. Portanto, indivíduos e, especialmente, jovens indivíduos que convivem com um mundo imaginário global, consideram a pluralidade das variações de "vidas possíveis" (APPADURAI, 1998).

\footnotetext{
${ }^{6}$ Isto não significa que a globalização necessariamente deixa de reforçar identidades e culturas locais. Inclusive, a recente ascensão de virulentos micro-nacionalismos e fundamentalismos religiosos apontam nessa direção. Contudo, aquelas tentativas de reforçar culturas locais e particularismos identitários deveriam ser interpretadas nos termos de uma resistência à globalização que, todavia, não é desnaturalizada por isso, ao mesmo tempo em que, não obstante, é afetada conjunturalmente.
} 


\section{MODERNIZAÇÃO REFLEXIVA E INDIVIDUALIZAÇÃO}

\section{Modernização reflexiva}

Desenvolvia até aqui a discussão dos determinantes estruturais das globais mudanças econômicas, políticas e culturais experimentadas pelas sociedades por todo 0 mundo. Ainda que sistemas culturais e políticos sigam suas próprias leis e não possam ser simplesmente reduzidos a epifenômenos do sistema econômico, está claro que o desenvolvimento de suas formas respectivas são interdependentes ao desenvolvimento do último. Desde esta perspectiva, mesmo a emergência de uma cultura global, que é criada como vimos através da crescente interconectividade entre várias culturas locais, não pode ser desligada do processo de globalização econômica. Contudo, se nós não queremos construir um quadro unidimensional no qual as estruturas sobredeterminam as ações locais, então, a perspectiva estrutural da economia política dos fluxos deve ser acrescentada a uma perspectiva mais voluntarista, na qual seja explorado o poder que os indivíduos têm em relação às estruturas sociais. Precisamente, se nós queremos considerar a possibilidade de uma contestação contra-hegemônica ao capitalismo neo-liberal, devemos inverter 0 mencionado quadro para tentarmos tratar como as estruturas globais são crescentemente dependentes de ações locais. A coordenação de ações locais dirigidas reflexivamente contra 0 sistema tem 0 potencial de transformá-lo. Com vistas a alcançar tal reversão de perspectiva, usarei a teoria da modernização reflexiva tal como Anthony Giddens, Ulrich Beck e Scott Lash recentemente desenvolveram (BECK; GIDDENS; LASH, 1994). ${ }^{7}$

0 conceito de "modernização reflexiva" foi introduzido primeiramente por Beck em seu influente livro sobre a sociedade do risco (BECK, 1986). Nesse livro que apareceu na semana do desastre nuclear de Chernobyl e exerceu grande influência não apenas nos círculos da teoria social alemã, mas também na opinião pública alemã -, Beck apresentou uma contra-resposta à celebração de Daniel Bell ao advento da sociedade pós-industrial. A expressão "sociedade do risco" refere-se a uma fase do desenvolvimento da sociedade moderna na qual os perigos e os riscos se tornam tão proeminentes que, mudam e eventualmente, solapam 0 arranjo moderno da sociedade do capitalismo industrial que os gerou. Uma vez que na sociedade do risco a "produção social de riqueza" é sistematicamente correlativa à "produção social de riscos", então, a velha política da distribuição de

\footnotetext{
${ }^{7}$ A teoria da modernização reflexiva de Beck é uma teoria geral da modernidade que contém e integra três projetos teóricos sob uma singular fractualidade: a teoria da sociedade do risco, a teoria da individualização e a teoria do cosmopolitanismo, as quais foram trabalhadas posteriormente em uma trilogia e para além do curso deste artigo.
} 
"bens" (rendimentos, emprego, segurança social) da sociedade industrial apresenta uma nova política de distribuição de "males" (ameaças e riscos) (BECK, 1986, p. 25-27).

Os riscos resultantes, induzidos e introduzidos pela própria modernidade, tornam-se um dos mais frequentes temas na esfera privada e pública de discussão. Comparado aos perigos da sociedade industrial - eles inevitavelmente ocorrem - os riscos da sociedade de risco são socialmente manufaturados e pressupõem a consciência de uma potencial ameaça, cuja ocorrência pode ser prognosticada e cuja probabilidade pode ser estatisticamente premeditada; mesmo se nenhum plano de seguro puder nos proteger. Os perigos ambientais representados pelos acidentes químicos e nucleares em larga escala, e pela engenharia genética, podem levar a auto-aniquilação à espécie humana. Além disso, os riscos modernos não são espacialmente limitados em seus efeitos, mas ameaçam sociedades inteiras. Eles são potencialmente globais em seu alcance. Como nuvens tóxicas, a radioatividade transcende fronteiras nacionais e não faz distinção entre classes. Os riscos, contudo, escapam à percepção sensorial e excedem nossa capacidade imaginativa. São cientistas que detectam riscos e definem o limiar do aceitável e, dessa maneira, ipso facto, aceitam certos riscos e propõem soluções para remediar. Por esse caminho, riscos são discursivamente mediados e socialmente construídos pelos especialistas científicos. Contudo, uma vez que especialistas são crescentemente contestados por um oposto especialista, por exemplo, aqueles do Greenpeace ou dos Friends of the Earth, então, as implicações políticas do gerenciamento científico dos riscos tornou-se visível não apenas aos próprios expertos, mas também a uma esfera pública mais ampla.

Sobre essa questão, torna-se claro que a sociologia de Beck é uma sociologia política do conhecimento, que objetiva atualizar o debate alemão dos anos de 1960, em torno da tecnocracia no bojo da virada pós-moderna. Não se trata de pensar Beck como pós-modernista. Em relação a essa discussão, Beck é muito mais habermasiano e formula uma teoria do "esclarecimento ecológico" (BECK, 1991, p. 117-139). Ele incorpora os argumentos sobre insegurança epistemológica, a ausência de fundamentos do conhecimento, bem como, a desconstrução do logo(falo)centrismo e os transpõe do nível abstrato da teoria social pós-moderna à vida cotidiana. Cresce o número de cidadãos céticos quanto às promessas do progresso científico e tecnológico. Não hesitam em contestar os cientistas. Como resultado desse movimento de uma "teoria crítica da sociedade" para uma "teoria da autocrítica social" (BECK, 1993, p. 54), o pessimismo que cercava 0 velho debate sobre tecnocracia pode agora ser substituído pelo cauteloso otimismo político. Agora, quando os perigos da sociedade industrial passam mais 
ao domínio público, o projeto de tecnocracia é publicamente desmascarado como um projeto político. Por contiguidade, as "relações de definição", que levam às relações de produção na sociedade industrial, são reveladas pelo que realmente são: nomeadamente, "relações de poder" que cientificamente legitimam potenciais desastres políticos da sociedade do risco (BECK, 1988, p. 211-216, 220226). Portanto, o inimigo ainda é o mesmo - a tecnocracia -, contudo, agora que virou um inimigo público ele tem de legitimar publicamente seu projeto tecnocrático como projeto político. Por fim, posto que tal projeto político potencialmente conduz a catástrofes, ele está mais e mais contestado pela sociedade em geral, resultando, portanto, no ganho da primazia da moralidade e da política sobre as deliberações científicas.

Embora 0 sociólogo alemão esteja preocupado, principalmente, com as consequências ecológicas da sociedade industrial e não tenha muito a dizer sobre as consequências sociais da globalização econômica, seus argumentos podem ser para aí estendidos. Aliás, poderia ser argumentado que da mesma maneira pela qual a população vem tornando-se cética quanto aos expertos da ciência, também tem começado a questionar a expertise dos economistas, por exemplo, aqueles oriundos do Banco Mundial ou do Fundo Monetário Internacional que, cientificamente, produzem a legitimação das políticas neo-liberais da "flexploração" global, apresentando-as como uma necessidade inelutável se a economia nacional pretende permanecer competitiva no mercado global. 0 resultado dessa contestação ao consenso neoliberal é uma possível repolitização da economia desnaturalizando as leis de mercado e expondo a maneira como os expertos científicos estão cegos para os riscos ecológicos da cultura industrial da produtividade, os economistas estão cegos para os riscos sociais da cultura do capitalismo rentabilista.

De acordo com Beck, a crise ecológica não é apenas uma crise do meio ambiente, mas uma genuína crise social que revela o desmoronamento nas fundações da sociedade do capitalismo industrial. Nos finais do século XX, a industrialização e a racionalização formal se tornaram um problema. Beck argumenta que 0 avanço da modernização industrial acabou por solapar a própria modernização levando, por esta razão, ao advento da "segunda modernidade", na qual as consequências danosas do exuberante industrialismo se tornaram um tópico da preocupação pública. Ao contrário do cenário apocalíptico da Dialética do esclarecimento da Escola de Frankfurt, Beck argumenta que o sucesso do capitalismo industrial não conduz à integração de toda resistência possível ao status quo, mas que, por outro lado, desencadeou um novo tipo de crise de 
legitimação na qual a crise ecológica agora adquire o papel do que uma vez Habermas atribuiu à crise econômica do capitalismo tardio (HABERMAS, 1975).

Confrontada com a crise das vacas loucas, do aquecimento global e da possibilidade de um inverno nuclear, a população em geral tende a assumir a postura cética quanto às promessas do progresso científico como tal. A ideologia tecnocrática, que representa o contraponto tecnológico à doutrina econômica do laissez-faire, perde paulatinamente sua credibilidade (FREITAG, 1989, p. 62). Como resultado desse desafio à autoridade da ciência e da tecnologia, o "véu tecnológico" (Marcuse) que, de maneira fetichista deturpa as decisões políticas apresentando-as falsamente como decisões técnicas, é rasgado. A população tornase consciente do fato de que os perigos ecológicos são produzidos socialmente e de que, inclusive, catástrofes naturais resultam da intervenção do Homem em sua relação com a natureza. Confrontados com as consequências das políticas da industrialização, a sociedade industrial tende a tornar-se reflexiva, o que significa dizer tornar-se, pela força das circunstâncias, ela própria um tema e um problema.

A indicada auto-tematização e auto-problematização da sociedade industrial está no centro da teoria de Beck sobre a modernização reflexiva (BECK, 1991, p. 180-194; 1993, p. 35-69; 1995, p. 11-30; BECK; GIDDENS; LASH, 1994, p. 1-13). 0 argumento principal dessa teoria é o de que a busca da modernidade industrial minou os próprios fundamentos da sociedade industrial, que, por sua vez, foi conduzida a uma "modernização da modernização" abrindo caminho para modernidade alternativa e ecologicamente inteligente. Isto teve lugar nesse argumento porque a acumulação de consequências perversas da modernidade industrial produz ameaças sistemáticas as quais não podem ser resolvidas e assimiladas pelo próprio sistema da sociedade industrial. Eventualmente, a população torna-se mais consciente desse fato. Nessa medida, vemos a autodestruição da sociedade industrial, não obstante, destruição paradoxal que abre caminho para outra consciência de realidade.

Uma vez mais, portanto, Beck inverte o fatalismo industrial da Escola de Frankfurt: mais racionalização formal não conduz à crescente reificação, mas eventualmente a diminui. Dois passos podem ser distinguidos no processo de desreificação. Primeiramente, a lógica autônoma do sistema reificado cria consequências perversas não-intencionais, porém, sistemáticas. Esses efeitos perversos ameaçam a sobrevivência do sistema e não podem ser resolvidas dentro do sistema (dissolvendo a crise ecológica criada pelo controle científico e tecnológico dos seus efeitos ou dissolvendo o problema do emprego de massa 
enquanto dedica-se às políticas neo-liberais de globalização). Em segundo lugar, confrontada com 0 risco de autoaniquilação do sistema, a população torna-se consciente das causas sistemáticas de esses riscos, soa o sinal de alarme, submete o sistema a uma crítica sistemática e generalizada chamando por mudanças políticas fundamentais do sistema.

Uma vez que a crise passa do sistema para o mundo da vida, o próprio sistema torna-se crescentemente dependente da legitimação pelo mundo da vida. A "gaiola de ferro da modernidade" despedaça-se. Os atores não querem reproduzir as estruturas, mas falam em nome de sua transformação. A clássica dialética de atores e estruturas está fracassada, se não invertida. As próprias estruturas tornam-se 0 objeto do processo social de debate e de mudança. Confrontados com os efeitos sociais e ecológicos de uma política tecnocraticamente implementada, com vistas ao desenvolvimento econômico global, os cidadãos se tornam desconfiados em relação ao sistema político como tal, retiram-se dele e refugiam-se no mundo da vida, onde desenvolvem formas alternativas de vida as quais não são sem consequências políticas diretas para 0 amplo sistema.

\section{Industrialização reflexiva}

A teoria da modernização reflexiva não substitui a análise moralmente inspirada de Habermas sobre a crise de legitimação do capitalismo tardio (HABERMAS, 1975), mas complementa-a com uma dimensão ecológica. A "contradição básica" entre o funcionamento do capitalismo e a lógica da democracia permanece, contudo, não por muito tempo poderá ser justificada desde o ponto de vista de uma moralidade pós-convencional. Os membros da sociedade industrial capitalista não aceitarão o preço social e ecológico da política de desenvolvimento e, por sua vez, demandam por uma transformação democrática e radical de seus fundamentos. Ambas as teorias, basicamente, formulam uma teoria dos efeitos políticos do déficit de uma legitimação moralmente induzida ao qual as sociedades capitalistas industriais estão confrontadas quando consideradas a partir do critério pós-materialista da moralidade pós-convencional. Sociologicamente observando, ambas as teorias pressupõem que os indivíduos se liberam em relação às estruturas sociais e são capazes de se distanciar reflexivamente das tradições e dos modos convencionais de pensamento e julgamento pelos quais foram socializados para, então, criticamente pensar por si próprios. Em outras palavras, "modernização reflexiva" pressupõe "individualização reflexiva". 
A tese da individualização como foi avançada por Beck (1986, p. 205-219; 1995, p. 31-41) e Giddens (1991) desenvolve a afirmação (simmeliana) de que sob as condições da alta modernidade os indivíduos (jovens de classe média) cada vez mais estão livres ("freigesetzt") não só dos constrangimentos culturais, tais como a religião, a tradição, a moralidade convencional, a incondicional crença na validade da ciência; como também dos constrangimentos estruturais, tais como classe, status, nação, gênero e família nuclear. ${ }^{8}$ Como a força vinculante das formas herdadas da vida social é dissolvida, então, indivíduos poderiam refletir sobre as implicações dos processos culturais e estruturais e, por este caminho, escolher em qual deles se envolverão. Resultando disso, é claro, a auto-identidade tornou-se um empenho organizado reflexivamente. 0 que um dia foi inerente à tradição e dado por certo, já agora, requer um decisão consciente pelo indivíduo para se perpetuar. Nesses termos, identidade não é mais atribuída, porém atingida. Como Peter Berger (1979, p. 16) disse: "0 que antigamente era sorte, agora é lugar de escolhas. Ou: o destino está transformado em decisão." Aliás, confrontados com a pluralidade dos mundos da vida e dos estilos de vida, indivíduos devem agora produzir, apresentar e rascunhar constantemente suas biografias eles próprios. Biografia, portanto, tornou-se, como Berger disse bem antes de Beck e Giddens, um "projeto desenhado". "0 indivíduo não apenas planeja o que fazer, mas também planeja o que ser" (BERGER, P.; BERGER, B.; KELLNER, 1974, p. 74).

0 núcleo da tese da individualização, nos termos de Beck e Giddens, é a assunção de que, uma vez que indivíduos (jovens de classe média) estão livres das coerções estruturais e culturais, então, desenham reflexivamente suas próprias biografias. Reformulado nos termos da clássica oposição entre agência e estrutura (e cultura), a qual é agora deslocada de problema metodológico para problema sócio-histórico, nós devemos dizer que individualização implica agência liberada da estrutura (e cultura). Contudo, a individualização é um processo altamente dialético na medida em que é devido às coerções estruturais e culturais que a agência se libera. De fato, o processo de individualização reflexiva não ocorre em um vácuo social, mas é a consequência de uma transformação radical de (i) condições culturais (destradicionalização, globalização cultural e cientificização da

\footnotetext{
${ }^{8}$ Para consulta no marco da discussão sobre a tese da individualização, conferir também Beck e Beck-Gernsheim (1994), e Heelas, Lash e Morris (1996). Beck e Giddens apresentam o processo da individualização como um processo que afeta a todos/as na modernidade tardia. Na última parte do presente artigo, analisarei as condições materiais da reflexividade (nos termos de Beck e Giddens) e a restringirei ao escopo da tese da individualização das juventudes de classe média.
} 
conduta) e de (ii) condições estruturais (o mercado de trabalho) da baixa modernidade.

Em relação às condições culturais, nosso mundo é um mundo póstradicional no qual o modelo parsoniano, de uma idílica e bem integrada complementaridade entre o sistema social, o sistema cultural e o sistema de personalidade, foi dissolvido pela "institucionalização da reflexividade" (SCHELSKY, 1965). Os elementos do sistema cultural não são simples ou quase automaticamente interiorizados pelos indivíduos, mas como Schelsky notara já no final dos anos de 1950, as tradições culturais tornaram-se reflexivas, tornaram-se o tema de discussão. Por consequência, uma vez submetidas à discussão, sua validade foi necessariamente enfraquecida, pois as tradições apenas conservam suas forças de validade se suas pretensões não são questionadas, mas antes aceitas como valor normativo.

De mais a mais, em um mundo global, tradições culturais locais não estão isoladas de outras, mas começam a misturar-se e a interpenetrar-se. Nesse quadro, culturas locais necessariamente têm sua validade relativizada, e a tradição pode vir a tornar-se opcional. Nós podemos viver como um Rastafári em São Paulo e como um Paulistano na Etiópia. A difusão global dos meios de comunicação de massa e a pluralização dos estilos de vida que elas celebram frisam 0 caráter opcional dos modelos culturais.

Ampliando este quadro está o fato de que crescentemente estamos dependentes de peritos em sistemas de informação; nossas ações do cotidiano cada vez mais incorporam o conhecimento dos especialistas dos mais diferentes tipos. Por seu lado, estes peritos são essencialmente falíveis, contestáveis, contestados. Isso faz tornar claro que a dúvida radical que caracteriza a teoria pósmoderna agora permeia o mundo da vida como tal.

0 resultado da combinação entre destradicionalização, globalização cultural e cientificização da vida cotidiana é o de que indivíduos estão confrontados com vertiginosa gama de modelos de conduta disponíveis e que eles não têm outra escolha a não ser escolher por si próprio o que decidirão seguir. Juntamente, pesa o fato de que não há garantias de que sua escolha será acertada para si, portanto, sua escolha é necessariamente um risco para si.

Em relação às condições estruturais, o mercado de trabalho capitalista permanece a principal instituição das sociedades contemporâneas. De acordo com Beck, 0 mercado de trabalho é também o principal motor a partir do qual deriva 0 processo de individualização reflexiva das formas de vida do futuro (BECK, 1986, p. 115-160; BECK; BECK-GERNSHEIM, 1994, p. 43-60). Este é o caso da 
probabilidade de encontrar um emprego no mercado de trabalho estar sistematicamente ligada ao prolongamento do período de escolarização, mobilidade frequente e competição crescente, cada uma das quais contribui para a individualização de sua própria maneira. A escolarização substitui modos tradicionais de conhecimento por modos mais universalistas e reflexivos; mobilidades social e geográfica dissolvem os laços primários de sociabilidade e forçam a interpretar seu destino como destino pessoal; a competição por escassas posições conduz ao isolamento em relação aos pares. Além disso, os processos de globalização econômica induziram a uma radical flexibilização do mercado de trabalho, tomado por desemprego massivo, um levante espetacular nos contratos de trabalho por curta duração e difusa insegurança econômica como resultado. Embora esta insegurança econômica seja sistematicamente induzida pelos processos de globalização econômica, é interpretada pelo indivíduo como falha majoritariamente pessoal. Este fato, unido ao declínio da importância do trabalho como fonte de auto-identidade, aponta para o porquê de uma falta de consciência e de solidariedade de classe.

Esta dissolução da consciência de classe não pode ser compensada, contudo, por um refúgio na família tradicional. Este caminho está também barrado, não apenas porque a entrada da mulher no mercado de trabalho está conectada ao mesmo processo de individualização, mas o processo de emancipação da mulher dissolveu amplamente a instituição da família nuclear. Agora que as mulheres pagam seu próprio imposto de renda, estão relativamente menos dependentes de seus maridos e podem experimentar formas não tradicionais de relações íntimas, tais como, a coabitação, o amásio, a bi e/ou homossexualidade, a reprodução independente, etc. Confrontados com a pluralidade de alternativas à família nuclear tradicional, indivíduos são forçados a escolher, por eles mesmos, a qual opção se empregar (BECK; BECK-GERNSHEIM, 1990).

Frequentemente é assumido que esta liberação dos indivíduos (jovens de classe média), em relação a constrangimentos estruturais e culturais, conduziu a uma atomização da sociedade na qual a anomia é predominante e a autonomia é impossível. No entanto, em divergência a ambas as críticas à esquerda - as quais argumentam, como vimos, que indivíduos estão apenas liberados da instituiçãosociedade para, então, serem recuperados pela sociedade e manipulados pelo mercado; por outro lado, os da direita que lamentam o declínio moral do ocidente sem indiciar o mercado neo-liberal -, eu gostaria de defender a reivindicação heurística de que anomia e autonomia não são necessariamente excludentes entre si, mas podem, e atualmente o fazem, incluir uma em outra. 
Não nego que individualização e anomia podem caminhar juntas, todavia, anomia apenas pode ser interpretada como séria ameaça ao indivíduo e à sociedade, se considerada em relação a um pano de fundo da bem integrada ordem nômica do passado. Entretanto, na sociedade pós-industrial, tal ordem nômica não ocupa mais posição de prevalência. Ao contrário, às pessoas é atribuído o dever de escolher por si qual modelo de conduta seguirão. Bem dito, tal fato não é sem riscos para um indivíduo em questão ou para a sociedade em geral. Não obstante, ao mesmo tempo, há indícios empíricos de que 0 falecimento de valores tradicionais não corresponde necessariamente a niilismo, mas aponta para elevada ênfase na qualidade de vida e nas instituições políticas democráticas.

A "teoria da mudança dos valores intergeracionais" de Inglehart (1977) tem sido confirmada em nossos dias. Historicamente sem precedentes, o grau de segurança econômica experimentado pela geração do pós-guerra, na maioria das sociedades industriais, conduziu a uma troca gradual de "valores materialistas" (enfatizando segurança econômica e física para todos) para "prioridades pósmaterialistas" (enfatizando expressão de si, autonomia e qualidade de vida). Atualmente, materialistas e pós-materialistas podem ser contados em quase igual número, enquanto em 1970 materialistas superavam quatro vezes em número os pós-materialistas.

A recente análise de Inglehart sobre os Surveys Mundiais de Valores - com dados de 60.000 respondentes de 43 sociedades que representam $70 \%$ da população mundial - consistentemente confirma sua tese do cambio "pósmodernista", em geral, e do "pós-materialista", em particular, ocorrido nos últimos 35 anos, especialmente entre as "comitivas juvenis" das sociedades ocidentais (INGLEHART, 2008). A confiança em autoridades religiosas, políticas e científicas está declinando; em simultâneo, indivíduos voltam a si em um impulso de massa por mais participação e expressão de si. Quanto à participação política, a tônica recai sobre a troca de ênfase do voto em benefício de partidos tradicionais para formas de participação massiva mais ativas e por temas específicos. Quanto ao comportamento econômico, a troca de ênfase alterna entre o maximizar os rendimentos de trabalho e a crescente insistência sobre o emprego significativo e interessante para si. Quanto às normas sexuais e à vida em família, as normas tradicionais têm sido substituídas pela grande flexibilidade em prol da escolha individual no comportamento sexual, inclusive, apresenta uma dramática elevação da aceitação das formas de comportamento sexuais externos ao casamento e à heterossexualidade. No terreno dos valores normativamente fundamentais, 0 declínio da confiança nas Igrejas é acompanhado por uma crescente preocupação espiritual quanto ao significado e propósito da vida. Dessa maneira, esses indícios 
demonstram convincentemente que não estamos tanto testemunhando uma perda de valores, porém, bem um conflito entre valores materialistas e pósmaterialistas.

\section{JUVENTUDES E MUDANÇA SOCIAL NA MODERNIDADE TARDIA}

\section{Juventudes - definição sociológica}

0 estudo das juventudes oferece uma oportunidade ideal para examinar a relevâncias das teorias da mudança social na modernidade tardia. Se os processos de globalização, modernização reflexiva e individualização têm mudado fundamentalmente os contornos das sociedades modernas, como Giddens e Beck afirmaram, esperaríamos encontrar evidências fortes dessas mudanças entre as populações juvenis. De fato, nós encontramos. Se nós definimos juventude não em termos biológicos, como uma fase fisiológica, começando com a puberdade e terminando com a maturidade sexual, ou em termos psicológicos como uma fase estendida através das várias fases da adolescência e pós-adolescência, mas como uma categoria social, modulada por instituições particulares, especialmente, educação, mercado de trabalho, família e papéis sociais, tais como, adquirir títulos escolares, deixar a casa precedente, obter emprego, formar família (FORNÄS, 1995, p. 3), podemos conceber a juventude como uma fase de transição relativamente estendida entre a infância e a idade adulta. Esta última marcada por três transições de status, nomeadamente: transição profissional (deixar a dedicação integral à educação e inserir-se no mercado de trabalho), a transição doméstica (alcançar relativa independência da família de nascimento) e a transição de moradia (sair da casa dos pais) (GALLAND, 1995).

Até a chegada dos anos de 1970, o curso da vida das populações juvenis era altamente estruturado ao longo dos marcadores de classe e gênero e relativamente padronizado. Para os jovens homens da classe operária, o limiar da transição de status tendia a coincidir de tal maneira que completar os estudos era usualmente acompanhado de perto pela inauguração da vida de trabalhador o que, por consequência, permitia deixar a casa dos pais e viver como casal. Enquanto os jovens homens de classe média deviam adiar indefinidamente o limiar que marca a transição de status, manter suas opções abertas e mudar seu percurso como preferirem. Por outro lado, mulheres suprimiam o estágio ocupacional, deixavam a casa de seus pais para casar e passar a residir com o cônjuge.

Nas últimas décadas, mudanças estruturais na sociedade convergiram para a desestruturação do mercado de trabalho e mudanças culturais para a 
destradicionalização dos padrões de comportamento. Essas mudanças impactaram as relações entre as populações juvenis e a família, os amigos, suas experiências em educação e em empregabilidade, além disso, sua habilidade para se tornar estabelecido na posição de jovem adulto, para a qual uma série prolongada de transições tem sido significativamente estendida, senão adiada completamente, e o curso da vida segmentado e individualizado.

Metaforicamente, a biografia padronizada de tempos idos, descrita em termos de transição de status, pode ser vista em termos de jornadas por estrada de trem (FURLONG; CARTMEL, 1997, p. 6-7). A partir da escola, populações juvenis preparam-se juntas com destino a diferentes destinatários de vida. As formações alçadas são determinadas desigualmente pelos marcadores de classe social, gênero, etnia e êxitos educacionais. Uma vez iniciada a jornada de trem, as oportunidades interruptivas para alterar a destinação são bastante limitadas. As mudanças nos últimos vinte anos, as quais convergiram, inclusive, para a substituição das biografias padronizadas pelas flexibilizadas, orquestradas e individualizadas pelo modelo "biografia da escolha", podem ser mais bem descritas nos termos do fechamento por atacado das estradas de ferro dos trens. Com a ausência de trens, a jornada é agora empreendida de carro. Dessa maneira, os motoristas ganham a dita oportunidade de selecionar suas rotas dentre uma vasta coleção de alternativas. Dada a flexibilização do mercado de trabalho, somos tentados a dizer que o curso da vida de um número significante de populações juvenis - que não podem se dar ao luxo de possuir um carro e necessitam depender do transporte público privatizado - consiste em "longos períodos de espera expostos à chuva no ponto de ônibus por um transporte de qualquer tipo para chegar lá".

A despadronização e individualização do curso da vida das populações juvenis confirmam a referida tese de Beck e Giddens. Ao mesmo tempo, a tese da individualização tende a obscurecer o fato de que os processos de globalização neo-liberal afetam seriamente 0 campo de possibilidades da vida das pessoas e 0 fato de que as relações sociais de desigualdade permanecem no peso de uma vida ao longo dos anos. Embora as condições materiais coletivas da vida social se façam mais obscuras, continuam provendo um poderoso enquadramento que, diretamente, constrange o campo de possibilidades de vida e, indiretamente, 0 estilo de vida de uma parte majoritária da população. Em teoria, diz-se que todas as pessoas possuem a oportunidade de refletir sobre sua vida e escolher livremente seu percurso e estilo de vida; na prática, contudo, reflexividade permanece ostensivamente uma prerrogativa exclusiva de pessoas jovens, homens, brancos e membros da classe média. Já Bauman disse que "a 
responsabilidade individual para escolher é igualmente distribuída, não as condições para agir sobre a responsabilidade" (BAUMAN, 1997, p. 196).

0 problema em Beck e Giddens está no fato de que eles ignoram amplamente as bases de classe, etnia, gênero e de idade da reflexividade. Os tipos de práticas reflexivas anunciadas por eles pressupõem que os interesses materiais estão satisfeitos e, em conseqüência, que os indivíduos podem distanciar a si próprio de suas necessidades imediatas e do mundo sensível para poder refletir sobre estruturas sociais. Por este caminho, a determinação das estruturas sociais é insignificante e, a despeito delas, os indivíduos podem decidir sobre os seus papéis, sobre o que ignorar, sobre o que se opor e assim por diante.

A adoção de uma perspectiva bourdiesiana (BOURDIEU, 1979) permitirá observar que não é universal a capacidade de colocar a si à distancia das relações para, então, refletir sobre elas. Ao contrário. Esta capacidade é parte das competências do babitus de classe associado aos acadêmicos e às classes médias intelectualizadas. Além disso, na medida em que a relação entre a satisfação das necessidades materiais e a capacidade de reflexão não é um produto imediato, mas reflete as condições que prevaleceram durante o processo de socialização, então, argumentaríamos com Inglehart (1977) que os processos de individualização reflexiva são característicos não de todas as idades, mas, sobretudo, das jovens gerações. Usando uma vez mais a metáfora do transporte, sumarizaríamos a discussão da tese da individualização ao dizer: o transporte público foi substituído pelo carro privado, mas a classe, a etnia e o gênero ainda assim determina significativamente a trajetória do curso de vida das populações juvenis. Portanto, Beck e Giddens fracassam quanto à percepção de que "o tipo de carro (ex. Porsche ou Skoda) que um jovem aluga no início da jornada permanece o mais significante predecessor do fundamental resultado" (FURLONG; CARTMEL, 1997, p. 7).

Olhando mais detalhes da "desestruturação estruturada" das transições de status que definem as juventudes como categoria social, podemos ver que 0 regulador das mudanças que interferiram no curso da vida na Europa, nas últimas décadas, está primeiramente induzido pelas mudanças econômicas globais na direção de um mercado de trabalho pós-industrial flexível (CAVALLI; GALLAND, 1995; FURLONG; CARTMEL, 1997). A partir da crescente e agressiva demanda por altos níveis de qualificação na idade mínima, permitida juridicamente para trabalho, populações juvenis de todas as classes sociais estão atualmente permanecendo por muito mais tempo na cadeia de escolarização, em regime de dedicação exclusiva até avançada idade. A educação de ensino superior 
está se tornando uma experiência massiva ao invés de protetorado de uma pequena elite.

Tais mudanças convergiram para uma procrastinação e diversificação das transições da escola para o emprego. Aliás, na medida em que as posições no mercado de trabalho podem ainda ser razoavelmente preditas com exatidão, segundo 0 indicador de classe social (via desempenho educacional), aquelas transições permanecem altamente estratificadas. Novas formas de "flexploração" têm reduzido a segurança empregatícia e muitas das mais qualificadas populações juvenis permanecem aprisionadas no mercado de trabalho periférico em relação à sua formação e, como se não bastasse, estão altamente vulneráveis ao desemprego periódico.

A crise e a alta amplitude sem precedentes dos índices de desemprego (mais da metade dos jovens entre 16 e 24 anos estão desempregados na Grécia, Portugal e na Espanha) apenas acentuou a indicada tendência. A despeito da recuperação econômica, a situação não é menos trágica nos Estados Unidos (WACQUANT, 2009). Como Coffield (1997, p. 61) disse irreverentemente, populações juvenis na Europa estão sendo "estocadas da mesma maneira que a política agrícola ordinária criou montanhas de cereais e manteiga excedentes". Nos Estados Unidos, a situação é pior (WACQUANT, 2009). Não há rede de segurança financeira e a marginalização e criminalização das populações juvenis negras super empobrecidas ("underclass") configuram um quadro no qual, atualmente, há mais jovens negros nas cadeias do que no ensino superior. Prisões reduzidas ao papel de "distrito policial superlotado" (BAUMAN, 1998, p. 120), não mais esboçam reeducar os jovens criminalizados que, então, são "despejados" e "estocados" em massa em prisões privatizadas.

No sul da Europa, especialmente na Itália ("mamismo"), grande parte dos jovens tende a continuar a viver na residência dos pais até completarem seus trinta anos e, por subsequência, a casar rápido depois de deixarem a casa dos pais. No norte da Europa, tendem a deixar a casa dos pais cedo e cada vez mais aumenta a probabilidade de despenderem longo tempo residindo em casas intermediarias antes de organizarem a própria casa. Em todos os casos, a transição doméstica não é acompanhada pela transição da habitação. Essa tendência à procrastinação e ao adiamento da transição doméstica e habitacional, notável através de classes e gênero, é parte de um processo mais amplo de "confortabilização" ("gentrification") dos percursos e estilos de vida. Incorporando elementos da cultura de classes operárias nas classes médias e viceversa, as divisões de classes estão embaçadas atualmente. No entanto, mesmo se a 
distribuição dos estilos de vida está se tornando mais democrática, por outro lado, a distribuição das possibilidades de vida permanece aristocrática em hierarquia.

A distinção entre, por uma parte, possibilidades de vida, as quais estão diretamente determinadas pelo capital econômico e indiretamente por cultura; e, por outra parte, estilos de vida, os quais estão indiretamente determinados por dinheiro e diretamente por capital cultural, permite-nos, já agora, especificar a gama de teses da individualização e esclarecer o paradoxo da modernidade tardia. Objetivamente, o capitalismo está mais forte do que nunca. A "causalidade do provável", ao delimitar a possível trajetória social de um dado indivíduo e determinar sua probabilidade de possibilidades de vida, permanece sobredeterminada pela posição de classe. Aliás, subjetivamente, a consciência de classe tem minguado - talvez desfigurado completamente. Tendo por referência a base de cálculo "indivíduo", ao invés de culpar o sistema ou olhar para soluções coletivas, indivíduos culpam a si mesmos por suas inseguranças sociais e precárias soluções. Nesses termos, o capitalismo tardio igualar-se-ia ao capitalismo sem marxismo. A desfiguração da consciência de classe é realçada e estimulada pela mercadorização da cultura e a comercialização dos estilos de vida, os quais sistematicamente burlam as divisões estratificadas (de classe, gênero e etnia), por consequência, mascarando os privilégios das populações juvenis de classes médias e cimentando, dessa maneira, a pseudo-nietzschiana ilusão de que cada um pode ser o que é.

\section{Novos movimentos sociais}

Apesar da persistência das desiguais relações sociais, a velha política dos movimentos operários está hoje completamente fora do compasso da realidade. A deposição revolucionária do capitalismo não pertence mais à agenda. De encontro ao acordo neo-corporativo entre o Estado, os empregadores e os sindicatos, 0 conflito de classe foi progressivamente institucionalizado. Desde os anos de 1970, 0 acordo neo-corporativo tem acumulado em si um grave esgotamento. Se as globalizações econômica e política erodiram os poderes tradicionais do Estado desde cima, o humor anticorporativo dos posmaterialistas e a reação violenta neoliberal atacaram o Estado desde baixo (CROOK; PAKULSKI; WATERS, 1992, p. 83-105; OFFE, 1985b, p. 817-825).

0 colapso do acordo neocorporativo e a mudança em direção ao posmaterialismo têm feito o paradigma da política tradicional, crescentemente, inadequado para 0 entendimento do caráter político da modernidade tardia. 
Sindicatos e partidos políticos são ainda assim importantes, é claro. Não obstante, externamente ao sistema corporativo, novos movimentos sociais (NMS), tais como os feministas, ecológicos e movimentos juvenis, têm emergido em contestação ao sistema existente e competido com os poderes de elite pela construção do poder político. Embora aqueles NMS sejam forças extra-parlamentares ou extrainstitucionais que emanam do mundo da vida, ainda assim são forças políticas na medida em que aspiram redirecionar e transformar não apenas o sistema político como tal, porém o extenso sistema econômico e social em geral. Se nós não revisarmos completamente os velhos paradigmas da política, sua significância política inevitavelmente escapará de nós, assim como procuraremos pela política "no lugar errado, nos domínios errados e nas páginas erradas dos jornais" (BECK; GIDDENS; LASH, 1994, p. 18).

Se nós compararmos as políticas da elite-dirigente das classes trabalhadoras ou do movimento operário - as quais foram o paradigmático "velho" movimento social - às políticas da elite-desafiante dos NMS, poderemos notar importantes diferenças a respeito da localização de: a) a determinação de classe; b) os objetivos; c) a organização, e d) o processo político dos movimentos (CALHOUN, 1993; COHEN, 1985; MELUCCI, 1996; SCOTT, 1990).

a) As políticas dos NMS são "movediças" (dinâmicas) ao invés de "estáticas" em orientação. Localizados no seio da sociedade civil, tendem a contornar o Estado e a tratarem pouco diretamente a contestação do Estado. Desconectados do antigo movimento operário, o qual era utópico em orientação e buscava reprisar o todo da sociedade em registro diferente através da deposição das relações de produção existentes, os NMS são defensivos em orientação. Eles aceitam o Estado democrático e a economia de mercado, não se esforçam por aboli-los, mas tentam domesticá-lo e transformá-lo democraticamente de maneira tal que 0 dinheiro e 0 poder não solapem as infraestruturas comunicativas, expressivas e emocionais do mundo da vida.

b) Atores envolvidos nos NMS não consideram a si próprios nos termos de classes socioeconômicas em primeiro lugar. Considerando que o processo de individualização reflexiva tem enfraquecido, talvez até dissolvido, a consciência e a solidariedade de classe, por conseguinte, identidades econômicas da política têm perdido sua saliência e estão sendo substituídas por uma mistura de identidades atribuídas (como etnia, idade ou gênero) e de identidades expressivas (como orientação sexual ou identificação com vários estilos vida de comunidades). Nesse sentido, Dubet (1994, p. 186) está correto quando declara que os movimentos sociais são "movimentos de indivíduos", mas ele se esquece de especificar que os 
atores vêm, primeiramente, dos segmentos jovens das "novas classes médias". Tal afinidade estrutural não se deve à experiência de juventude ou de classe média como classe, tampouco como idade-específica desempoderada, mas está vinculada ao fato de que os NMS atraem quem se identifica mais com valores pósmaterialistas (EDER, 1993, p. 158-184).

c) Em contraste com o mencionado antigo paradigma de movimentos sociais, os NMS são primeiramente culturais e sociais por natureza e, secundariamente, posicionam-se como políticos. Suas preocupações estão menos voltadas para o poder político e mais para a esfera cultural, seus focos de existência são menos os interesses materiais, porém mais os valores morais e estilos de vida expressivos. Criticando o modelo produtivista do movimento de classe operária, anteciparam uma variedade de outras problemáticas; as quais estão calcadas em aspectos voltados à vida pessoal (sexualidade, etnia, ecologia); estão preocupados com a democratização das estruturas da vida cotidiana ou privilegiam as formas expressivas de comunicação e a defesa da integridade do mundo da vida. Por este caminho, eles objetivam produzir mudança social através da mudança de valores, desenvolvendo, portanto, novos estilos de vida e mudando as identidades dos papéis sociais.

d) Os NMS abandonam o modo organizacional do movimento operário. Em vez de formarem sindicatos ou partidos políticos de cariz socialista, social democrata ou comunista, eles se concentram em comunidades de base e insistem sobre a bandeira de que as formas organizacionais e o estilo da prática dos movimentos devem exemplificar os valores que o movimento se empenha em promulgar. Consequentemente, muitos dos NMS estão comprometidos com 0 ideal de democracia direta, estruturas anti-hierárquicas e redes de relações informais. Em direção ao fim do milênio, novas formas de protestos emergiram na cena e adquiriram envergadura global. Fomentados pela revelação do obtuso projeto da WTO para radicalmente liberalizar as transações internacionais, a "Batalha de Seattle" em 1999 marcou a emergência do movimento antiglobalização e abriu a página de um novo capítulo na história dos novos movimentos sociais. Distraídos pelas sequelas do 11 de Setembro, o Movimento de Justiça Global (Global Justice Movement) lentamente apequenou-se enquanto, ao mesmo tempo, adquiriu institucionalidade no Fórum Social Mundial. 0 que permaneceu, todavia, foi uma miríade da coalizão de movimentos, mobilizações de ação direta, uso massivo de meios sociais e novas táticas de protestos (tais como a notoriedade da tática Black Bloc). A Primavera Árabe, o Ocuppy nos Estados Unidos, Los indignados na Espanha e os protestos no Brasil circunscrevem numerosas instâncias de um campo movediço de forças sociais. 
Mundialmente, neste cenário, contendas políticas ingressaram em uma nova fase. os tempos se mostram abertos ao novo dos Novos-Novos Movimentos Sociais.

Organizados em torno de agendas específicas, é flutuante em andamento e em número o conjunto de engajados ao mover dos movimentos. Nesse quadro, participantes se vinculam e se desengajam de acordo com 0 contexto político e com suas mudanças na vida pessoal. Nesse sentido, NMS representam "redes de relações ocultas" entre as relações informais que podem permanecer latentes para vir a "se tornar visível sempre que atores confrontam ou colocam-se em conflito com uma política pública" (MELUCCI, 1989, p. 70). Nestes termos, circunscrevendo as rotinas de eleição e pressionando pela domesticação do capitalismo, os NMS recolhem recursos para a ação direta e para novas táticas de democracia.

\section{Juventude - culturalmente definida}

Uma vez esboçadas as linhas de caracterização dos NMS, eu gostaria de concluir este artigo com algumas considerações sobre a importância das juventudes e da juvenilidade nesses movimentos. Inspirado em Dilthey e principalmente em Mannheim (1964), gostaria de apresentar uma definição conflitual e cultural de juventude, a qual enlaça as juventudes às convergências formativas do Zeitgeist em relação ao qual são uma forma de resposta. No mesmo passo, gostaria de insistir sobre 0 argumento de que o conflito de gerações pode ser tão influente quanto o conflito de classes. Contudo, para levar em conta a reflexividade da modernidade tardia, considero que deveríamos concentrar menos atenção sobre a influência do atual Zeitgeist dos anos de adolescência, como Mannheim preconiza, e mais focalizar a atual influência das formas de vida e dos estilos de vida das juventudes aos quais respondem. A juventude pode ser observada a partir da consideração de que, localizada entre os ciclos da vida, está ligada a processos abertos do pensamento que expressam a si mesma através do fato de que o indivíduo, consciente e seletivamente, orienta a si próprio entre alternativos estilos de vida. Na medida em que as juvenilidades caminham junto à recusa autoevidente, para seguir cegamente as tradicionais injunções e um desejo para experimentar com vidas alternativas e comunidades contraculturais, alguém pode ser ainda jovem aos 40 anos da mesma maneira que alguém pode ser idoso aos 25 anos. 0 que importa é simpatizar com e orientar a si próprio/a para as frações experimentais das populações juvenis, portanto, considerando não biologicamente as idades da vida. 
Pelas condições da individualização reflexiva, os indivíduos estão posicionados livres em relação às normas tradicionais de desenvolvimento e de engajamento do passado. Religião, tradição e moralidade convencional perderam suas forças respectivas e classe, status e nação, bem como o modelo hegemônico e normativo de família nuclear perderam sua capacidade de atração. Consequentemente, em relação a esse quadro, os indivíduos jovens são considerados cognitivamente e normativamente desorientados e anômicos, tanto quanto procuram por novos tipos de laços sociais. Apesar de tudo, a parte majoritária desse segmento da população recusa o retorno à referida medida de segurança do passado. ${ }^{9}$ Seus pais são um produto dos anos de 1960 e eles mesmos cresceram em uma situação de relativa seguridade socioeconômica. $\mathrm{Na}$ medida em que valores basilares refletem condições que prevaleceram durante os anos precedentes à idade adulta, constata-se a confirmação empírica da tese de Inglehart a respeito da mudança de valores intergeracionais: populações juvenis estão mais inclinadas para os valores pós-materialistas do que seus pais (INGLEHART, 1997, p. 131-159).

Halperns confirma essas afirmações quando nota que populações juvenis estão geralmente mais tolerantes, abrem mão de valores tradicionais e desejam maior medida de autodeterminação e de autorresponsabilidade (WILKINSON, 1997, p. 90). Aquelas diferenças entre o jovem e seus pais não resultam do fato de que as pessoas se tornaram mais intolerantes quando se tornam idosas, mas resulta da aceleração da virada intergeracional em direção ao pós-materialismo. Os dados preliminares do Survey sobre o mundo dos valores (2006-2013) são inconclusivos. Contudo, a presença massiva de populações juvenis nas ruas por protestos pode ser interpretada como uma violenta rejeição de valores materialistas e políticas neoliberais de austeridade.

Populações juvenis estão, em linhas gerais, mais críticas e mais politizadas em relação aos seus pais. Deixam-se observar sensíveis aos debates morais e, nesta direção, recusam-se a aceitar o inaceitável, tal como a discriminação racial, a violação de direitos humanos, 0 abuso sexual e a irresponsabilidade de organizações empresariais em relação ao meio ambiente. Ao mesmo tempo, eles se deixam mobilizar pela dor dos pobres e dos excluídos ao atuarem em

\footnotetext{
9 Em relação à maioria deles, confrontados contra uma "crise de erosão" e "insegurança ontológica", uma minoria das populações juvenis atendem à suposta construção das seguranças do passado. Aqueles que o fazem, constroem os contornos de um "tornar-se convencional", outros reforçam fundamentalismos desde os mais simples possíveis. Por fim, alguns ostentam vínculo com contra-movimentos neofacistas e racistas.
} 
associações voluntárias para doar cuidado a tais segmentos da condição humana Não aceitam mais a hipocrisia oriunda da prática político-partidária e tendem a repelir tal política. Claramente, não a política como tal, mas os rituais da política partidária institucionalizada: "0 que aparece à primeira vista como apatia política, de fato, representa uma profunda revolução cultural” (COHEN, 1997, p. 181).

Populações juvenis incessantemente se retiram da sociedade que eles recusam, mas tal retirada não é sem implicações políticas. A aparente despolitização caminha junto a uma repolitização, ou melhor, para usar a terminologia de Beck, caminha junto a uma "subpolitização" da sociedade (BECK, 1993, p. 149-171; BECK; GIDDENS; LASH, 1994, p. 13-23). Subpolíticas que, topologicamente, vêm do baixo e das margens. Baseadas em valores alternativos e estilos de vidas contraculturais, elas tentam influenciar a política institucional e mudar as regras do jogo. Subpolíticas são também "políticas existenciais (lifepolitics)" (GIDDENS, 1991, p. 214-231) ou biopolíticas. Elas têm menos a ver com a distribuição das chances da vida, mas, antes, com estilos de viver e concepções da "boa vida". Elas travam "disputas sobre como (tanto como indivíduos quanto como humanidade coletiva) nós devemos viver em um mundo onde o que é usado para fixar laços, pela natureza ou pela tradição é, já agora, tema de decisões humanas." (GIDDENS, 1994, 14-15).

As políticas existenciais não eliminam as "políticas emancipatórias" da decana esquerda, mas, sobretudo, suplementam a luta contra a exploração, a desigualdade e a opressão mediante a força da luta por formas moralmente afiançáveis e mediante 0 fomento à autoatualização e à autodeterminação. Fomento este que, por sua vez, populações juvenis prezam bastante. Por esta leitura, estão menos atraídos à interpretação marxista da sociedade e têm até mais simpatia para a interpretação anarco-comunista. Não obstante, a indicada atração é lida aqui em relação de completa consonância com o instável balanço entre desespero e utopia, que caracterizam a efervescência política e social em tempos de transição. Por conseguinte, se movimentos sociais transicionais emergiram dirigindo sua contestação, marcadamente, aos efeitos ecológicos e sociais das velhas políticas do capitalismo industrial, então, nós poderíamos esperar encontrar populações juvenis, na linha de frente das expressões dos novos-novos movimentos sociais. 


\section{REFERÊNCIAS}

ADORNO, Theodor W. Spätkapitalismus oder Industriegesellschaft? In: ADORNO, Theodor W. Gesam- melte Schriften 8.I. Frankfurt: Suhrkamp, 1972. p. 354-370.

ALBROW, Martin. The global age: state and society beyond modernity. Cambridge: Polity Press, 1996.

ALEXANDER, Jeffrey C. Modern, anti, post and neo: how social theories have tried to understand the 'new world' of 'our time". Zeitschrift für Soziologie, Bielefeld, v. 23, n. 3, p. 165-197, 1994.

AMIN, Ash. Post-fordism a reader. Oxford: Blackwell, 1994.

APPADURAI, Arjun. Disjuncture and difference in the global cultural economy. In: FEATHERSTONE, Mike (Ed.). Global culture: nationalism, globalization and modernity. London: Sage, 1990. p. 295-310.

APPADURAI, Arjun. Globale ethnische räume: bemerkungen zur entwicklung einer transnationalen Anthropologie. In: BECK, Ulrich. Perspektiven der weltgesellschaft. Frankfurt am Main: Suhrkamp, 1998. p. 11-40.

AXFORD, Barrie. The global system: economics, politics and culture. Cambridge: Polity Press, 1995.

BAUDRILLARD, Jean. Le miroir de la production ou l'illusion critique du matérialisme historique. Paris: Galilée, 1985.

BAUDRILLARD, Jean. Pour une critique de l'économie politique du signe. Paris: Gallimard, 1972.

BAUMAN, Zygmunt. Globalization: the human consequences. Cambridge: Polity Press, 1998.

BAUMAN, Zygmunt. Postmodernity and its discontents. Cambridge: Polity Press, 1997.

BECK, Ulrich. Risikogesellschaft: auf dem weg in eine andere moderne. Franfurt am Main: Suhrkamp, 1986.

BECK, Ulrich. Gegengifte: die organisierte unerantwortlichkeit. Franfurt am Main: Suhrkamp, 1988.

BECK, Ulrich. Politik in der risikogesellschaft: essays und analysen. Franfurt am Main: Suhrkamp, 1991.

BECK, Ulrich. Die erfindung des politischen: $\mathrm{zu}$ einer theorie reflexiver modernisierung. Frankfurt am Main. Suhrkamp, 1993. 
BECK, Ulrich. Die feindlose demokratie: ausgewählte aufsätze. Leipzig: Reclam, 1995.

BECK, Ulrich. Was ist globalisierung? Irrtümer des globalismus - antworten auf globalisierung. Frankfurt am Main: Suhrkamp, 1997.

BECK, Ulrich. Politik der globalisierung. Frankfurt am Main: Suhrkamp, 1998a.

BECK, Ulrich. Perspektiven der weltgesellschaft. Frankfurt am Main: Suhrkamp, $1998 b$.

BECK, Ulrich; BECK-GERNSHEIM, Elisabeth. Das ganz normale chaos der liebe. Frankfurt am Main: Suhrkamp, 1990.

BECK, Ulrich; BECK-GERNSHEIM, Elisabeth. Individualisierung in modernen gesellschaften. Frankfurt am Main: Suhrkamp, 1994.

BECK, Ulrich; GIDDENS, Anthony; LASH, Scott. Reflexive modernisation: politics, tradition and aesthetics in the modern social order. Cambridge: Polity Press, 1994.

BELL, Daniel. The coming of post-industrial society: a venture in social forecasting. London: Heinemann, 1974.

BERGER, Peter. The heretical imperative. Garden City: Doubleday, 1979.

BERGER, Peter, BERGER, Brigitte; KELLNER, Hansfried. The homeless mind: modernization and consciousness. New York: Vintage books, 1974.

BERMAN, Marshall. All that is solid melts into air: the experience of modernity. London: Verso, 1982.

BEST, Steven; KELLNER, Douglas. Postmodern theory: critical interrogations. New York: Guildford Press. 1991.

BOURDIEU, Pierre. La distinction: critique sociale du jugement. Paris: Minuit, 1979.

BOURDIEU, Pierre. Contre-feux: propos pour servir à la résistance contre l'invasion néo-libérale. Paris: Liber, 1998.

BOYER, Roger; SAILLARD, Yves (Ed). Théorie de la régulation. L'état des savoirs. Paris: La découverte, 2002.

CAILLÉ, Alain. Critique de la raison utilitaire: manifeste du mauss. Paris: La découverte, 1988.

CALHOUN, Craig. 'New social movements of early nineteenth century'. Social Science History, Durham, v. 17, n. 3, p. 385-427, 1993. 
CARDOSO, Fernando; FALETTO, Enzo. Dependencia e desenvolvimento na America Latina: ensaio de interpretação sociológica. Rio de Janeiro: Civilização Brasileira, 2004.

CAVALLI, Alessandro; GALLAND, Olivier. Youth in Europe. London: Pinter, 1995.

COCKROFT, James, FRANK, André G; JOHNSON, Dale. Dependence and underdevelopment: latin america's political economy. Garden City: Anchor books, 1972.

COFFIELD, Frank. 'Always the Trainee, Never the Employee? Increasingly protracted transitions in the UK'. In: CAVALLI, Alessandro; GALLAND, Olivier. Youth in Europe, London: Pinter, 1997. p. 45-62.

COHEN, Jean. 'Strategy or identity: new theoretical paradigms and contemporary social movements'. Social Research, New York, v. 52, n. 4, p. 663-716, 1985.

COHEN, Jean; ARATO, Andrew. Civil society and political theory. Cambridge: MIT Press, 1992.

COHEN, Phil. Rethinking the Youth Question: education, labour and cultural studies. London: Macmillan, 1997.

CONNOR, Steven. Postmodern culture: an introduction to theories of the contemporary. Oxford: Blackwell, 1989.

CROOK, Stephen, PAKULSKI, Jan; WATERS, Malcolm. Postmodernization: change in advanced societies. London: Sage, 1992.

DEWS, Peter. Logics of disintegration: post-structuralist thought and the claims of critical theory. London: Verso, 1987.

DUBET, François. Sociologie de l'expérience. Paris: Seuil, 1994.

EDER, Klaus. The new politics of class. social: movements and cultural dynamics in advanced societies. London: Sage, 1993.

FALK, Richard. On bumane governance: toward a new global politics. Cambridge: Polity Press. 1995.

FEATHERSTONE, Mike. Global culture: nationalism, globalization and modernity. London: Sage, 1990.

FEATHERSTONE, Mike. In pursuit of the postmodern: an introduction. Theory, Culture and Society, London, v. 5, p. 195-215, 1988. Não foi citado. 
FEATHERSTONE, Mike; LASH, Scott. Globalization, modernity and the spatialization of social theory. In: FEATHERSTONE, Mike, LASH, Scott; ROBERTSON, Roland (Ed.). Global modernities. London: Sage, 1995. p. 1-24.

FORNÄS, Johan. Youth culture and modernity. In: FORNÄS, Johan; BOLIN, Goran (Ed.). Youth culture in late modernity. London: Sage, 1995. p. 1-11.

FREITAG, Michel. La nature de la technique et le problème normatif posé par son émancipation contemporaine dans le technologisme et le technocratisme. Société, v. 4, p. 5-94, 1989.

FRIEDMAN, Jonathan. Global system, globalization and the parameters of modernity. In: FEATHERSTONE, Mike, LASH, Scott; ROBERTSON, Roland (Ed.). Global modernities. London: Sage, 1995. p. 69-90.

FURLONG, Andy; CARTMEL, Fred. Young people and social change: individualisation and risk in late society. Buckingham: Open University Press, 1997.

GALLAND, Olivier. Introduction. What is Youth?' In: CAVALLI, Alessandro: GALLAND, Olivier (Ed.). Youth in Europe. London: Pinter, 1995. p. 1-6.

GIDDENS, Anthony. Beyond left and right: the future of radical politics. Cambridge: Polity press, 1994.

GIDDENS, Anthony. Modernity and self-identity: self and society in the late modern age. Cambridge: Polity press, 1991.

GIDDENS, Anthony. The consequences of modernity. Cambridge: Polity press, 1990.

GIDDENS, Anthony. The nation-state and violence: volume two of a contemporary critique of historical materialism. Cambridge: Polity press, 1985.

HABERMAS, Jürgen. Der philosophische diskurs der moderne: zwölf vorlesungen. Frankfurt am Main: Suhrkamp, 1985.

HABERMAS, Jürgen. Die postnationale konstellation: politische essays. Frankfurt am Main: Suhrkamp, 1998b.

HABERMAS, Jürgen. Jenseits der nationalstaats? Bemerkungen zu folgeproblemen der wirtschaftlichen globalisierung. In: Beck, Ulrich. Politik der globalisierung. Frankfurt am Main: Suhrkamp, 1998a. p. 67-84.

HABERMAS, Jürgen. Legitimationsprobleme im spätkapitalismus. Frankfurt am Main: Suhrkamp, 1975. 
HANNERZ, Ulf. Cosmopolitans and locals in world culture. In: FEATHERSTONE, Mike (Ed.). Global culture: nationalism, globalization and modernity. London: Sage, 1990. p. 237-251.

HARVEY, David. The condition of postmodernity. Oxford: Blackwell, 1989.

HELD, David. Democracy and the global order: from the modern state to cosmopolitan governance. Cambridge: Polity press, 1995.

HELD, David. Democracy, the Nation-State and the Global System. In: HELD, David (Ed.). Political theory today. Cambridge: Polity press, 1991. p. 197-235.

HIRST, Paul; THOMPSON, Grahame. Globalisation in question: the international economy and the possibility of governance. Cambridge: Polity press, 1996.

HORKHEIMER, Max; ADORNO, Theodor W. Dialektik der aufklärung. Philosophische fragmente. Frankfurt am Main: Fisher, 1986.

HUNTINGTON, Samuel. Democracy's third wave. Journal of democracy, Baltimore, v. 2, n. 2, p.12-34, 1991.

INGLEHART, Ronald. Changing Values among Western Publics from 1970 to 2006. West European Politics, v. 31, n. 2, p. 130-146, 2008.

INGLEHART, Ronald. Modernization and postmodernization: cultural, economic, and political change in 43 societies. Princeton: Princeton University Press, 1997.

INGLEHART, Ronald. The silent revolution: changing values and political styles. Princeton: Princeton University Press, 1977.

JAMESON, Fredric. Postmodernism or, the cultural logic of late capitalism. London: Verso, 1991.

LASH, Scott. Sociology of postmodernism. London: Routledge, 1990.

LASH, Scott; URRY, Jhon. Economies of signs and space. London: Sage, 1994.

LASH, Scott; URRY, Jhon. The end of organized capitalism. Cambridge: Polity press, 1987.

MANNHEIM, Karl. Das Problem der generationen. In: MANNHEIM, Karl. Wissenssoziologie auswabl aus dem werk. Berlin: Luchterhand, 1964. p. 509565.

McGREW, Anthony. (Ed.) The transformation of democracy? Globalization and territorial democracy. Cambridge: Polity press, 1997. 
McGREW, Anthony. A Global society. In: HALL, Stuart; HELD, David; McGREW, Anthony (Ed.). Modernity and its futures. Cambridge: Polity press, 1992. p. 61153 .

MELUCCI, Alberto. Challenging codes: collective action in the information age. Cambridge: Cambridge University Press, 1996.

MELUCCI, Alberto. Nomads of the present: social movements and individual needs in contemporary society. London: Hutchinson, 1989.

MILLS, Charles Wright. The sociological imagination. Oxford: Oxford University Press, 1957.

MOORE, Barrington. The social origins of dictatorship and bureaucracy. Boston: Beacon press, 1966.

OFFE, Claus. Disorganized capitalism: contemporary transformations of work and politics. Cambridge: Polity press, 1985a.

OFFE, Claus. New social movements: challenging the boundaries of institutional politics. Social Research, New York, v. 52, n. 4, p. 817-868, 1985 b.

PARSONS, Talcott. Societies: comparative and evolutionary perspectives. Englewood Cliffs: Prentice hall, 1966.

PARSONS, Talcott. The evolution of societies. Englewood Cliffs: Prentice hall, 1977.

PIETERSE, Jan Nederveen. Globalization as hybridization. In: FEATHERSTONE, Mike; LASH, Scott; ROBERTSON, Roland (Ed.). Global modernities. London: Sage, 1995. p. 45-68.

RIFKIN, Jeremy. The end of work: the decline of the global labor force and the dawn of the post-market era. New York: Putnam, 1995.

ROBERTSON, Roland. Globalization: social theory and global culture. London: Sage, 1992.

ROBERTSON, Roland. Glocalisation: time-space and homogeneity-heterogeneity. In: FEATHERSTONE, Mike; LASH, Scott; ROBERTSON, Roland (Ed.). Global modernities. London: Sage, 1995. p. 25-44.

ROSENAU, James. Turbulence in world politics: a theory of change and continuity. Princeton: Princeton University Press, 1990.

SCHELSKY. Helmut. 1965, 'Ist die Dauerreflexion institutionalisierbar?', pp. 250276. In: Auf der Suche nach der Wirklichkeit. Düsseldorf. E. Diederichs Verlag.. 
SCHILLER, Herbert. Mass communications and American empire. Boston: Beacon press, 1969.

SCOTT, Alan. Ideology and the new social movements. London: Unwin Hyman, 1990.

SKLAIR, Leslie. Sociology of the global system. London: Prentice hall, 1991.

SMART, Barrry. Modern conditions, postmodern controversies. London: Routledge, 1992.

SZTOMPKA, Piotr, The sociology of social change. Oxford: Blackwell, 1993.

THOMPSON, John. The media and modernity: a social theory of the media. Cambridge: Polity press, 1995.

VANDENBERGHE, Frédéric, Post-ism or Positivism? A comparison between theories of reification and theories of post-modernity. In: GEYER, F. (Ed.). Alienation, ethnicity, and postmodernism. Westport: Greenwood press, 1996. p. 149-158.

VANDENBERGHE, Frédéric, Une histoire critique de la sociology allemande. Aliénation et réification. Paris: Editions de la Découverte, 1997-1998. 2 v.

VANDENBERGHE, Frédéric, What's critical about critical realism? Essays in reconstructive social theory. London: Routledge, 2014.

WACQUANT, Loïc. Punishing the poor: the neoliberal government of social insecurity. Durham: Duke University Press, 2009.

WATERS, Malcolm. Globalization. London: Routledge, 1995.

WEBSTER, Frank. Theories of the information society. London: Routledge, 1995.

WILKINSON, Helen. Kinder der freiheit. Ensteht eine neue ethik individueller und sozialer verantwortung? In: BECK, Ulrich. Kinder der freiheit. Frankfurt am Main: Suhrkamp, 1997. p. 85-123. 